\title{
Three new species of free-living nematodes from the South-East Atlantic Abyss (DIVA I Expedition)*
}

\author{
ALEXEI V. TCHESUNOV \\ Department of Invertebrate Zoology, Faculty of Biology, Moscow State University, Moscow, 119991, Russia. \\ E-mail: AVTchesunov@yandex.ru \\ *In: Martínez Arbizu, P. \& Brix, S. (Eds) (2008) Bringing Light into Deep-sea Biodiversity. Zootaxa, 1866, 1-574.
}

\begin{abstract}
Three new nematode species were found in the Angola Basin (south-east Atlantic Ocean) at depths of about $5500 \mathrm{~m}$. Paracyatholaimus diva sp. nov. (Cyatholaimidae) is characterised by outer labial and cephalic setae of about 3-5 $\mu \mathrm{m}$, multispiral amphidial fovea with six turns in males and four turns in females situated at the level of the dorsal tooth, buccal cavity armoured with only one prominent dorsal tooth, tail consisting of anterior conical and posterior slender cylindrical half portions, and six preanal midventral setose supplementary organs. Paracyatholaimus diva sp. nov. is most similar to Paracyatholaimus rotundus Gerlach, 1964 but differs by slightly longer body (936-1176 $\mu \mathrm{m} v e r s u s ~ 705 \mu \mathrm{m}$ ), tail shape (with clearly narrowed posterior half versus conical), six versus four supplementary organs of different shape. The genus Paracyatholaimus Micoletzky, 1923 is briefly reviewed. The genus now includes twenty-four valid species. Five species are considered as species inquirendae, mainly because of inadequate type material lacking adult stages and/ or incomplete descriptions. A pictorial guide for identification of the valid species of Paracyatholaimus is provided. Pomponema proximamphidum sp. nov. shares subapical position of the amphidial fovea and distinct lateral differentiation of the somatic cuticle with five Pomponema species: P. concinnum Wieser, 1954, P. corniculata Gourbault, $1980, P$. mirabile Cobb, 1917, P. multipapillatum Filipjev, 1922 and P. stomachor Wieser, 1954 but differs from them by tail length, longer posterior cylindrical portion of the tail, relative width of the amphidial fovea, position of the ventral pore and lesser number of supplementary organs. Desmodora striatocephala sp. nov. is well characterized by a combination of very large amphidial fovea occupying nearly the entire lateral surface of the cephalic capsule and thickened midventral preanal cuticle with a few supplementary papillae inserted therein in males. $D$. striatocephala sp. nov. differs from related species $D$. cuddlesae Inglis, 1963 and to some lesser degree with $D$. inflexa Wieser, 1954 with shorter body, relative tail length, bigger size of the amphidial fovea and lesser number of supplementary papillae.
\end{abstract}

Key words: Angola Basin, Cyatholaimidae, Desmodora, Desmodoridae, deep sea biodiversity, DIVA I expedition, marine nematodes, Paracyatholaimus, Pomponema, pictorial guide, taxonomy

\section{Introduction}

Deep-sea nematodes are known to be very rich in species numbers and most of the species still remain to be described (Fonseca et al. 2006). During the DIVA-I (Latitudinal Gradients of Deep-Sea Biodiversity in the Atlantic Ocean) expedition, nematode communities from the Angola Basin were investigated. The Angola Basin is situated off the Namibian and Angolan coast north of the Walvis Ridge where water depths reach almost $5500 \mathrm{~m}$. General data on the Angola Basin site and sample methods are published by Kröncke \& Türkay (2003) and Rose et al. (2005). 
Nematode communities of both stations 325 and 346 investigated are dominated by the families Chromadoridae (mostly Acantholaimus), Xyalidae, Monhysteridae and Oxystominidae, comprising together about $75 \%$ of the specimens. Paracyatholaimus diva sp. nov., Pomponema proximamphidum sp. nov. and Desmodora striatocephala sp. nov. constitute 3\%, $0.7 \%$ and $0.7-1.5 \%$ in their ssamples of stations 325,346 and 325346 , respectively. Three new species described here were chosen for the first communication because of their larger size. Following papers are intended to be successive reports on various nematode families. Although all three species are represented by quite of adult individuals suitable for description per thousand nematode specimens in two samples examined, I decide to establish new species because of their diagnostic distinctness.

\section{Material and methods}

Two abyssal stations, 325 and 346, in the Angola Basin were sampled during the DIVA-I campaign of the RV Meteor M48/1 from July 6 to August 2, 2000. Station 325 (19 ${ }^{\circ} 58.2^{`}$ S, $002^{\circ} 59.8^{\prime} \mathrm{E}$; depth: $\left.5448 \mathrm{~m}\right)$ is located $300 \mathrm{~km}$ southwest of station $346\left(16^{\circ} 17.0^{\prime} \mathrm{S}, 005^{\circ} 27.0^{\prime} \mathrm{E}\right.$; depth: $\left.5389 \mathrm{~m}\right)$. Food availability and sediment structure differed between the two stations. Total organic carbon was higher at station $346(0.62 \%)$ than at station $325(0.41 \%)$. Mud and chlorophyll- $a$ content turned out to be higher at station $325(98.94 \%, 1.72 \mu \mathrm{g} / \mathrm{g})$ compared to station $346(95.23 \%, 1.67 \mu \mathrm{g} / \mathrm{g})$.

Both stations were sampled using a Barnett's multicorer. Each core with a diameter of $9.6 \mathrm{~cm}$ consisted of the upper $5 \mathrm{~cm}$ layer of sediment; the surface of each core amounted to $72.4 \mathrm{~cm}^{2}$, the volume to $362 \mathrm{~cm}^{3}$. The upper $5 \mathrm{~cm}$ sediment was preserved in $5 \%$ formaldehyde solution on board. In the laboratory the fixed samples were washed through a $40-\mu \mathrm{m}$ mesh sieve with tap water. Meiofauna and organic material were extracted from the remaining sand particles by centrifugation with a colloidal silica polymer (Levasil) as flotation medium and kaolin to cover heavier particles. The centrifugation was repeated three times at $4000 \mathrm{rpm}$ for 6 min, respectively. After each centrifugation the floating matter was decanted and rinsed with tap water.

Nematodes were extracted and processed to glycerin by means of slow evaporation. Specimens were mounted into permanent glycerin slides with a paraffin-beeswax ring. Extraction of nematodes and preparation of slides were performed at DZMB-Senckenberg, Wilhelmshaven, Germany. I was provided with ready slides which were then studied with an Olympus BX51 light microscope equipped with Nomarski optics.

Slides with type specimens of these new species are deposited in the collection of DZMB-Senckenberg (German Centre for Marine Biodiversity Research), Südstrand 44, 26382 Wilhelmshaven, Germany.

Abbreviations. a—body length divided by maximum body diameter; a.d.—anal body diameter; am.w., $\mu \mathrm{m}$ —width of the amphid; am.w., \%—width of the amphid, as a percentage of corresponding body diameter; $b$ body length divided by pharyngeal length; c — body length divided by tail length; c'—-tail length in anal diameters; calc (calculated) - morphometric value calculated from drawings of published species descriptions; c.b.d.—corresponding body diameter; cheil.1.—cheilostoma length; o.l.s.—length of outer labial setae; c.s.length of cephalic setae; diam.c.s. - body diameter at the level of cephalic setae; diam.am.- -body diameter at the level of amphids; diam.n.r.-body diameter at the level of nerve ring; diam.ca.- body diameter at the level of cardia; diam.midb. - midbody diameter; dis.am. - distance from the cephalic apex to the anterior rim of the amphid; dist.tail part, \%-length of posterior cylindrical tail portion as a percentage of the entire tail; dis.v.pore - distance from the cephalic apex to the ventral pore; dors.t.1.—dorsal tooth length; gub.1. - gubernaculum length; L—body length; spic.arc—spicule length along the arch; spic.chord—spicule length along the chord; st.l.- total stoma length; st.w.-maximal stoma width; suppl.1.-length of preanal supplementary organs; suppl.n.- - number of preanal supplementary organs; termin sp.--length of terminal spinnerete tube; V - distance of vulva from anterior end as percentage of body length.

All measurements in $\mu \mathrm{m}$ unless otherwise stated. 


\section{TAXONOMY}

\section{Cyatholaimidae Filipjev, 1918 \\ Paracyatholaimus Micoletzky, 1923}

Wieser, 1954a: 26, emended

\section{Diagnosis}

Cuticle punctated, lateral differentiation hardly developed. Six outer labial sensilla + four cephalic sensilla setose, in a single circle. Amphidial fovea multispiral. Cheilostoma armoured with twelve rugae; distinct dorsal tooth, often supplemented with smaller subventral teeth and occasionally other denticles in the stegostoma. Precloacal ventromedian supplements as setae-like organs half inserted into the body. Gubernaculum hardly dilated at the distal end and devoid of denticles or serrations. Tail conical or with more or less slender cylindrical distal portion.

\section{Type species}

Cyatholaimus dubiosus Bütschli, 1874.

\section{List of valid species}

1 Paracyatholaimus arcticus Kreis, 1963. Kreis, 1963: 39-40, fig. 20 A-C; Iceland.

2 Paracyatholaimus botosaneanui Andrássy, 1973. Andrássy, 1973: 259-261, Abb. 9 A-C; Cuba.

3 Paracyatholaimus chilensis Gerlach, 1953. Gerlach, 1953b: 19-21, Abb. 9 a-e; Chile.

4 Paracyatholaimus diva sp. nov. Present paper.

5 Paracyatholaimus dubiosus (Bütschli, 1874). Bütschli, 1874: 48, fig. 31 a, b (=Cyatholaimus dubiosus); Kiel Bay. Micoletzky, 1922: 377 (to subgenus Paracyatholaimus). Meyl, 1954: 428-429, Abb. 2 a-f; (Mediterranean).

6 Paracyatholaimus duplicatus Gerlach, 1964. Gerlach, 1964b: 77-78, Abb. 5 a-d; Maldive Islands.

7 Paracyatholaimus helicellus Wieser, 1954. Wieser, 1954a: 27, fig. 107 a-c; Chile.

8 Paracyatholaimus intermedius (de Man, 1880). De Man, 1880: 16-17 (=Cyatholaimus intermedius); De Man, 1884: 52-54, fig. 25-25f (=Cyatholaimus intermedius); Kattegat. Gerlach, 1953a: 21-22, Abb. 5; Baltic Sea. Gerlach, 1965: 127-128, Abb. 9 a-c; Spitzbergen. Bussau, 1990: 170-172, Abb. 3 A-C; North Sea, coastal dunes.

9 Paracyatholaimus lewisi Coomans, Vincx \& Decraemer, 1985. Coomans et al., 1985: 268, fig. 2 A-F; Solomon Islands, freshwater pool on a coral island; no males described.

10 Paracyatholaimus occultus Gerlach, 1956. Gerlach, 1956: 91-92, Abb. 29 a-c; Kiel Bay.

11 Paracyatholaimus paucipapillatus Gerlach, 1955. Gerlach, 1955: 265-267, Abb. 7 a-e; El Salvador.

12 Paracyatholaimus pentodon Riemann, 1966. Riemann, 1966: 125-127, Abb. 31 a-e; North Sea. Platt \& Warwick, 1988: 282, fig. 128; East and West Scotland.

13 Paracyatholaimus pesavis Wieser \& Hopper, 1967: 268-269, pl. XVI, fig. 32 a-e; Florida.

14 Paracyatholaimus proximus (Bütschli, 1874). Bütschli, 1874: 49, fig. 30 a-b (=Cyatholaimus proximus); Kiel Bay. De Man, 1922: 239-240, fig. 28 a, b (=Cyatholaimus proximus); North Sea. Micoletzky, 1924: 140 (to subgenus Paracyatholaimus).

15 Paracyatholaimus pugettensis Wieser \& Hopper, 1967. Wieser, 1959: 37-38, fig. 35 a-c (=Longicyatholaimus quadriseta Wieser, 1959, nec L. quadriseta Wieser 1954); Puget Sound, Washington, USA. Wieser \& Hopper, 1967: 265.

16 Paracyatholaimus quadriseta (Wieser, 1954). Wieser, 1954a: 13, fig. 98 a, b (=Longicyatholaimus quadriseta); Chile. Hopper, 1972: 69 (=Marilynia quadriseta).

17 Paracyatholaimus rotundus Gerlach, 1964. Gerlach, 1964a: 25, Abb. 2 d-e; Red Sea.

18 Paracyatholaimus saradi Gerlach, 1967. Gerlach, 1967: 30-31, Abb. 15 a-e; Red Sea.

19 Paracyatholaimus separatus Wieser, 1954. Wieser, 1954b: 194-196, Abb. 12 a-c; Mediterranean. 
20 Paracyatholaimus spinulosus Jensen, 1985. Jensen, 1985: 253-254, fig. 7 A-F; Gulf of Mexico.

21 Paracyatholaimus ternus Wieser, 1954. Wieser, 1954a: 27-28, fig. 108 a-e; Chile.

22 Paracyatholaimus truncatus (Cobb, 1914 ). Cobb, 1914: 60-62, fig. 17 (=Cyatholaimus truncatus); Florida, fresh or brackish water. Micoletzky, 1922: 377 (to subgenus Paracyatholaimus). Finding of Riemann (1970) in a similar habitat at the Caribbean coast of Colombia may be doubtful because of the lesser male body length (1050 vs $1600 \mu \mathrm{m})$, strong conical inner labial papillae, other pattern of four preanal supplementary organs (both posteriormost and penultimate organs are situated at the level of spicules while those of the type specimen are separated by much greater distances).

23 Paracyatholaimus vancouverensis Sharma \& Vincx, 1982: 276-278, fig. 15-23; British Columbia.

24 Paracyatholaimus vitraeus Gerlach, 1957. Gerlach, 1957: 140-141, Abb. 21 1-o; Brazil.

Remarks to species composition of the genus Paracyatholaimus

Four species originally assigned to Paracyatholaimus, i.e. choanolaimoides Stekhoven, 1942, effilatus Stekhoven, 1946, major Kreis, 1928 and tyrrhenicus Brunetti, 1949, were later transferred to other genera by various authors (Gerlach \& Riemann 1973) and are not considered here.

Twenty-seven species of Paracyatholaimus are enumerated in the NeMys (Deprez et al. 2005) where P. parasaveljevi Allgén, 1935 is designated species inquirenda. Here four more other species are considered as species inquirendae because of insufficient type material lacking adult stages and/ or incomplete descriptions:

Cyatholaimus chungsani Hoeppli et Chu, 1932; China. The species was shifted to Paracyatholaimus by Meyl (1954) and, missing in the NeMys list, is here considered as species inquirenda because of the very poor original description even lacking details actually indicating its affiliation with Paracyatholaimus. This is one of three species ascribed to Paracyatholaimus which were found in fresh-water habitats.

Paracyatholaimus exilis (Cobb, 1898) Micoletzky, 1924 (= Cyatholaimus e. Cobb, 1898); Australia. The original description is based on only a female specimen and lacks illustrations.

Paracyatholaimus oistospiculoides (Allgén, 1935) Wieser, 1954 (= Paracanthonchus o. Allgén, 1935); Norway Sea. The original description and drawings based on a single male specimen are too poor to determine the genus.

Paracyatholaimus parasaveljevi Allgén, 1935; Norway Sea. Wieser (1954a) qualified the species as species inquirenda.

Paracyatholaimus tenuispiculum (Allgén, 1951) Wieser, 1954 (= Paracanthonchus t. Allgén, 1951); Hawaii. The original description and drawings are based on a single male specimen and lacks many details such as amphids and length of anterior setae.

Illustrated guide for species of Paracyatholaimus (Figs $1 \& 2$, Table 1)

The guide is a set of simplified images (Figs $1 \& 2$ ) constructed in some accordance with the approved practice of Platt (1984) and others (e.g., Platt \& Warwick, 1998). Species of Paracyatholaimus differ from one another in rather fine morphological details concerning mainly length of anterior setae, number of turns in the multispiral amphidial fovea, supplementary organs and copulatory apparatus. The species can neither be disposed in a morphological continuum nor grouped in any evident morphological clusters. Therefore, it is not easy to develop a convenient polytomous or dichotomous key. I arrange the images of species in alphabetical order. An important component of the guide is Table 1, where the most important morphometric data are summarized. 


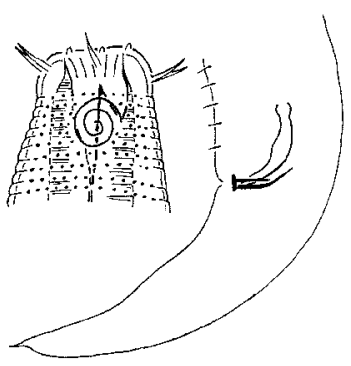

arcticus

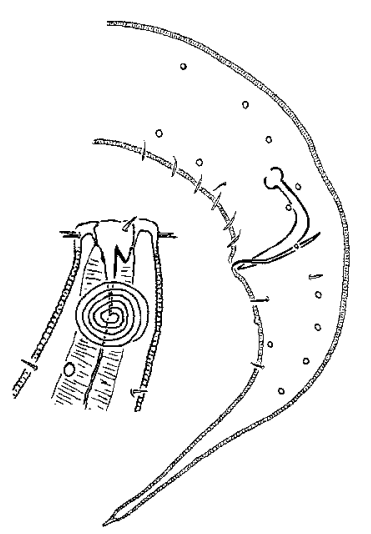

diva

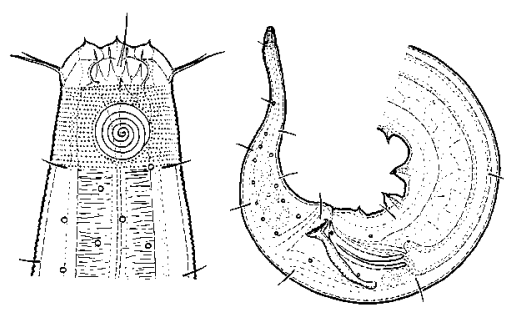

botosaneanui
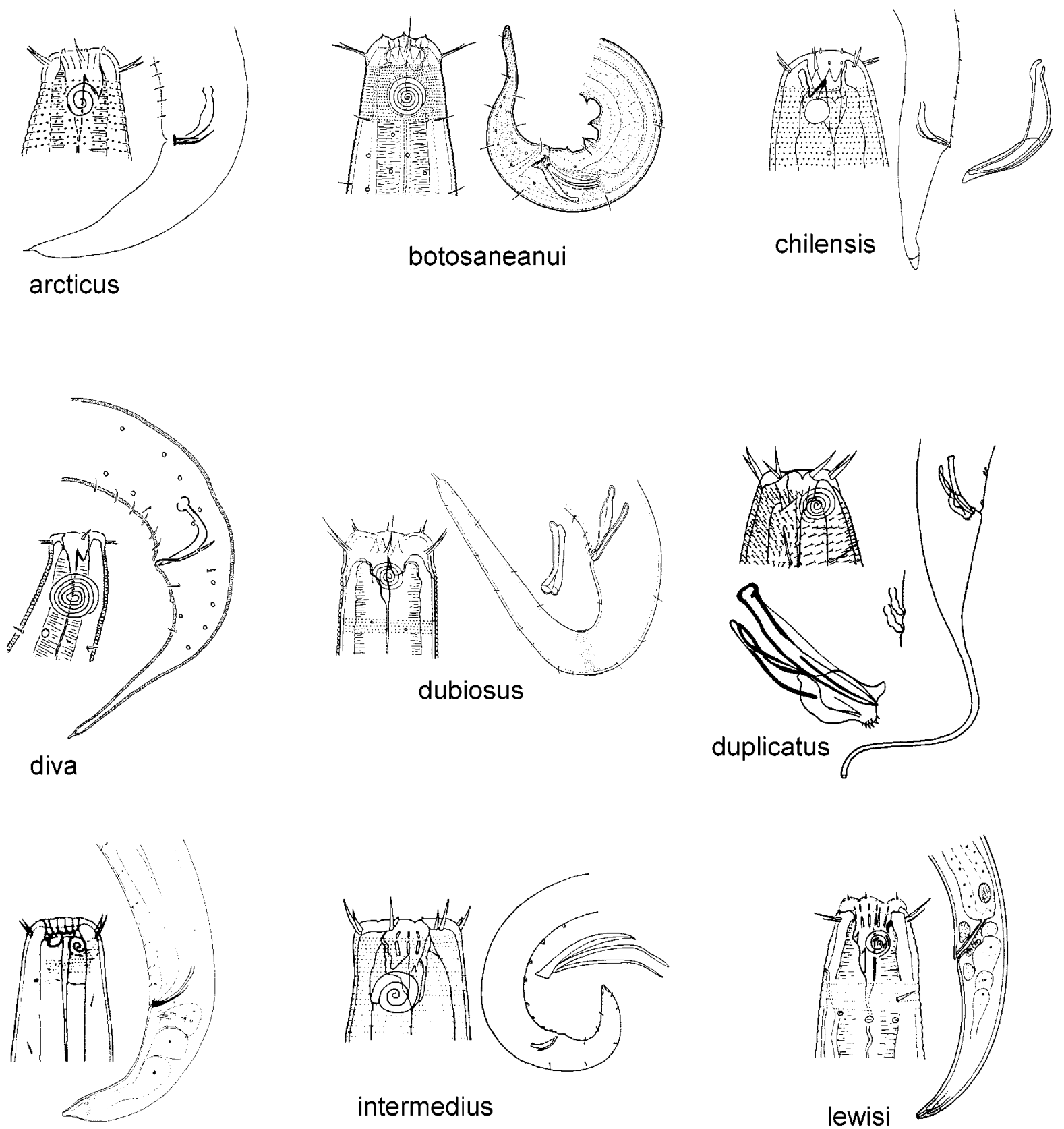

intermedius

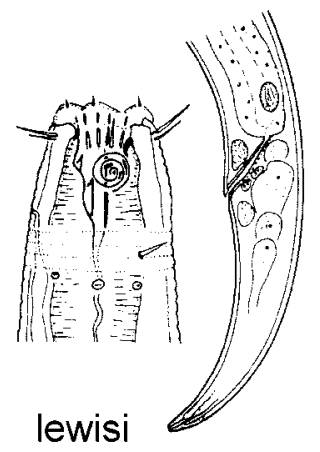

helicellus
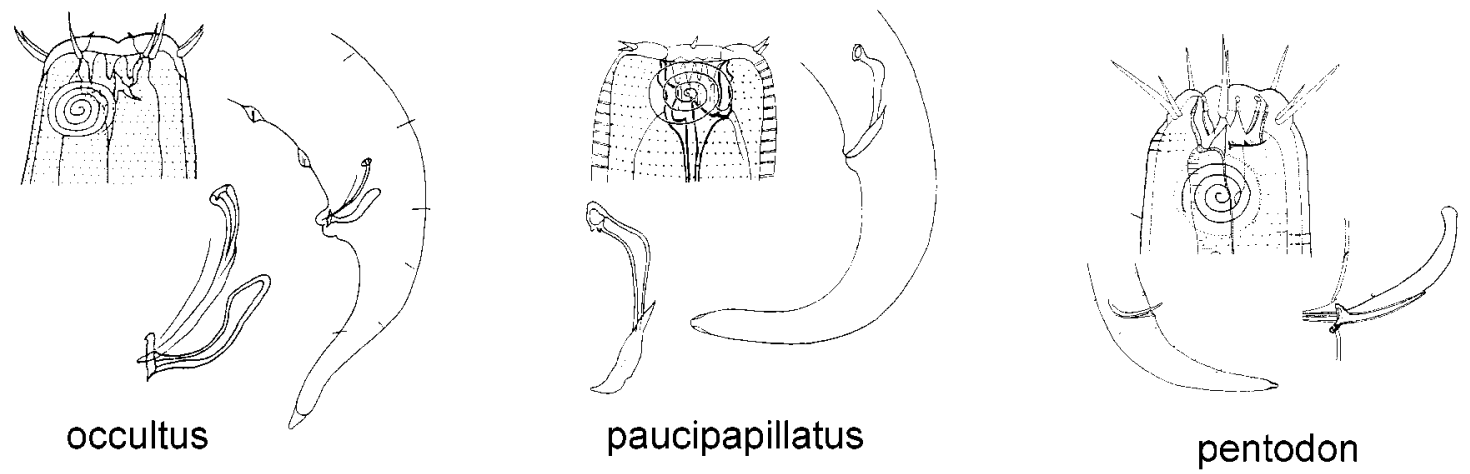

FIGURE 1. Pictorial guide for valid species of Paracyatholaimus. Part 1, beginning. Simplified images of species come from the published descriptions: arcticus—Kreis, 1963; botosaneanui-Andrássy, 1973; chilensis—Gerlach, 1953b; diva—orig.; dubiosus—Meyl, 1954; duplicatus_Gerlach, 1964b; helicellus—Wieser, 1954a; intermedius_Gerlach, 1953a; lewisi—Coomans et al., 1985; occultus —Gerlach, 1956; paucipapillatus—Gerlach, 1955; pentodon—Riemann, 1966. 

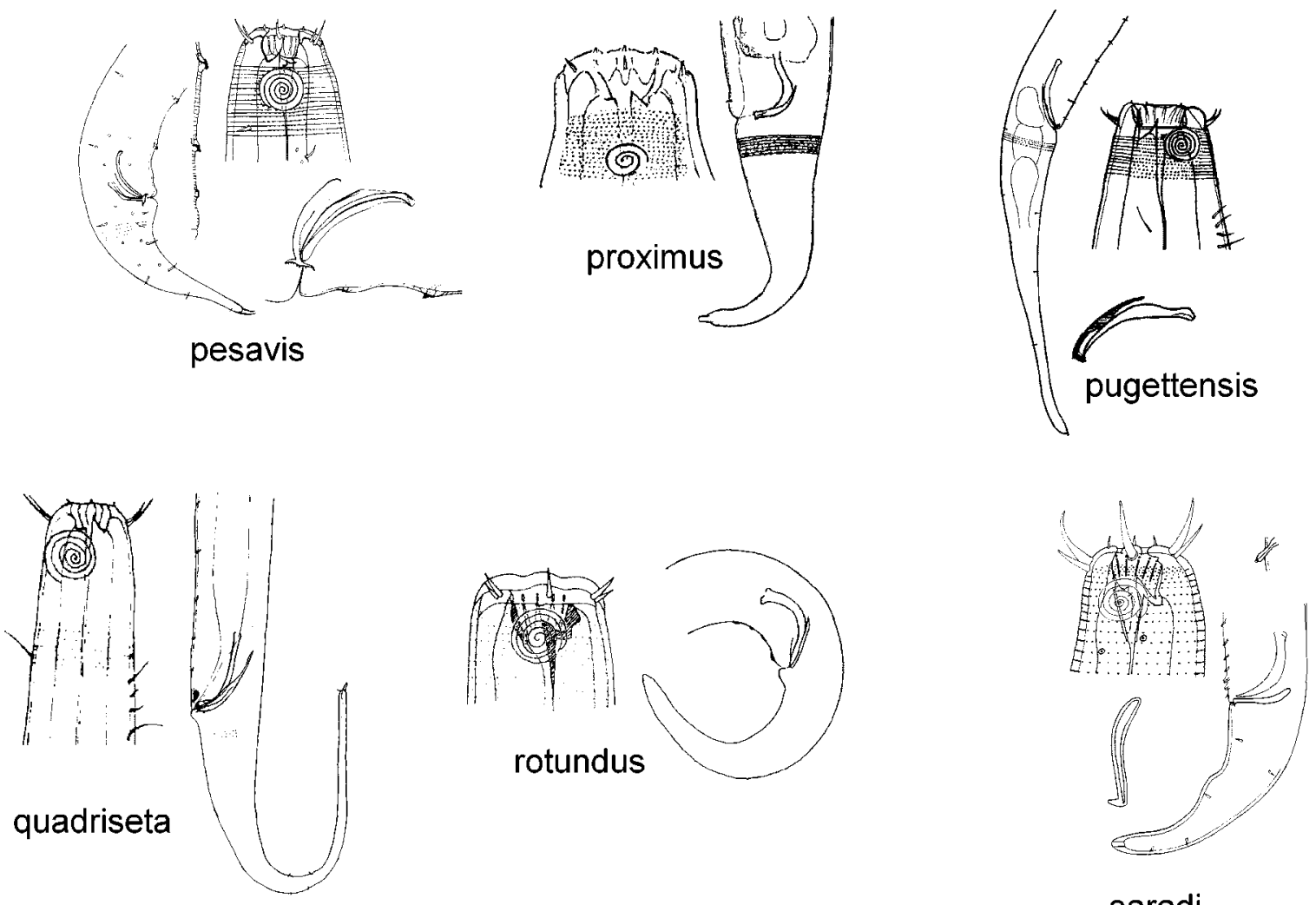

saradi
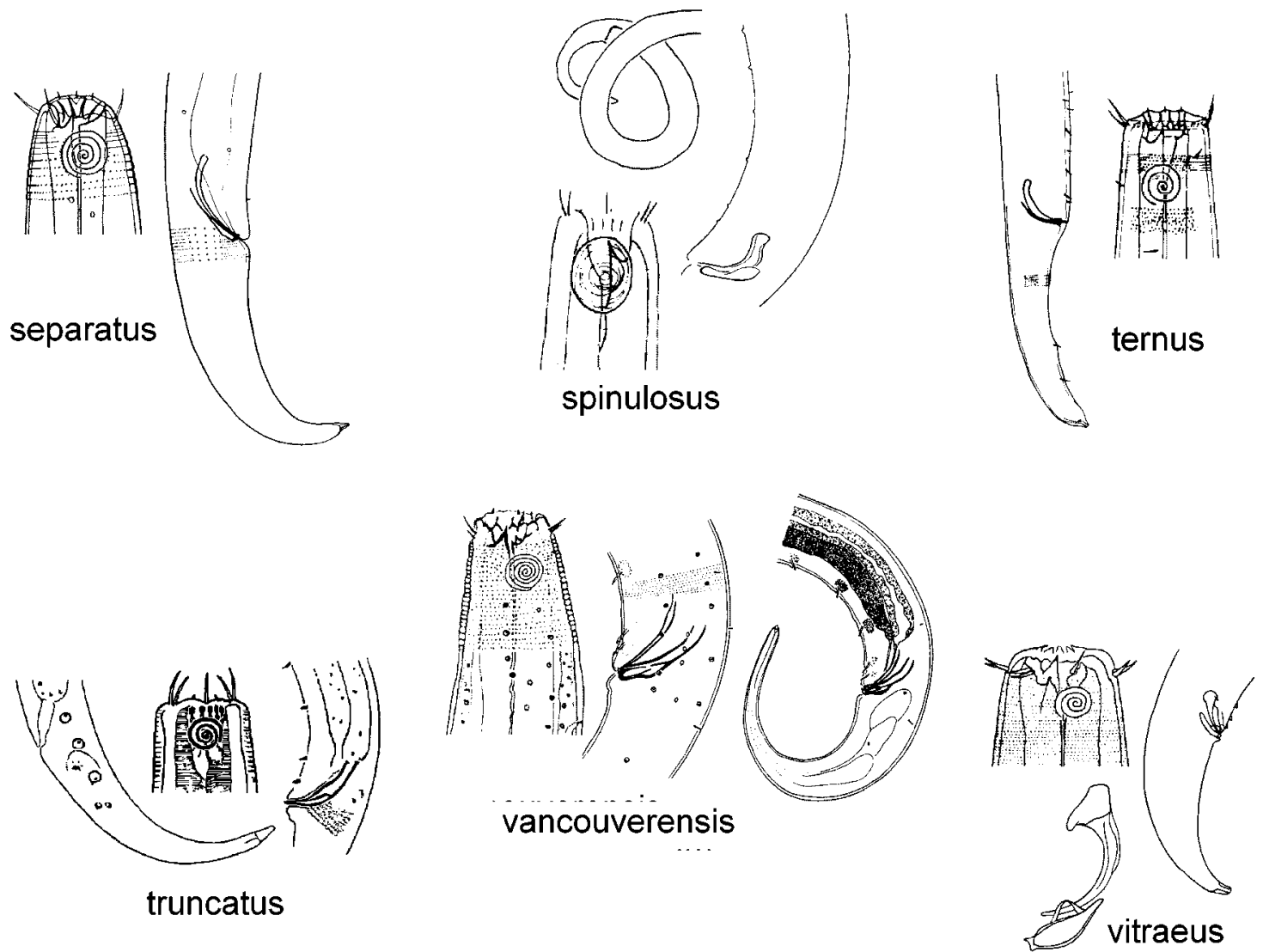

FIGURE 2. Pictorial guide for valid species of Paracyatholaimus. Part 2, ending. Simplified images of species come from the published descriptions: pesavis-Wieser \& Hopper, 1967; proximus-de Man, 1922; pugettensis-Wieser, 1959; quadriseta-Wieser, 1954a; rotundus-Gerlach, 1964a; saradi-Gerlach, 1967; separatus-Wieser, 1954b; spinulosus_Jensen, 1985; ternus-Wieser, 1954a; truncatus-Cobb, 1914; vancouverensis—Sharma \& Vincx, 1982; vitraeus-Gerlach, 1957. 
TABLE 1. Morphometry of valid Paracyatholaimus species (males).

\begin{tabular}{|c|c|c|c|c|c|c|c|c|c|}
\hline \multirow[t]{2}{*}{ Species } & \multicolumn{9}{|c|}{ Characters } \\
\hline & $\mathbf{L}$ & $\mathbf{a}$ & $\mathbf{c}$ & o.l.s., $\mu \mathrm{m}$ & $\begin{array}{c}\text { am.w., } \mu \mathrm{m}, \\
\% \text { c.b.d. }\end{array}$ & $\begin{array}{l}\text { amphid, } \\
\text { number } \\
\text { of turns }\end{array}$ & c' & spic., $\mu \mathrm{m}$ & suppl. n. \\
\hline arcticus & $789-925$ & $22.8-25.3$ & $9.8-11.7$ & 5.7 & 7.7 & 2.5 & 3.07 & 25-27 (chord) & $5-6$ \\
\hline botosaneanui & $1170-1400$ & $31-33$ & $13.5-15$ & $10-12$ & $9-10$ & $5-5.5$ & $3-3.3$ & $26-28$ & 4 \\
\hline chilensis & 1256 & 21 & 14 & 5 & $\begin{array}{l}33 \% \text { c.b.d., } \\
\text { hardly } \\
\text { discernible }\end{array}$ & 3 & $\begin{array}{l}2.53 \\
\text { calc }\end{array}$ & $36-39$ & 7 \\
\hline diva & $936-1176$ & $23.8-28$ & $7.45-8.86$ & $3-4$ & $12.5-14$ & 6 & $\begin{array}{l}3.02- \\
3.43\end{array}$ & $\begin{array}{l}34-36 \text { (chord), } \\
45-51 \text { (arch) }\end{array}$ & 6 \\
\hline dubiosus & $1092-1326$ & $25.5-31.5$ & $11-13.2$ & $8-12$ calc & $\begin{array}{l}8 \text { calc } \\
32 \% \text { calc }\end{array}$ & 4.5 & 5.5 & $25-31$ & 4 \\
\hline duplicatus & 1485 & 21 & 5.4 & $7-8$ & 12 & 5 & $5.5-6.5$ & 48 & $6(2+2+2)$ \\
\hline helicellus & $1410-1820$ & $28.3-32$ & $13.7-16$ & $7-7.5$ & $5.5,23 \%$ & 2 & 2.6 & 40 & 9 \\
\hline intermedius & $740-1575$ & $21.2-34$ & $9-14$ & $7-10$ & 9 & $3-4$ & 3 calc & $28-36$ & $4-9$ \\
\hline occultus & 1295 & 36 & 11.3 & $4-5$ & 14 & 4 & $3.5-4$ & 36 & 0 \\
\hline paucipapillatus & $1445-1860$ & $22-28$ & $13.9-14.1$ & $8-15$ & $42 \%$ calc & $5-6$ & 2.5 & $35-48$ & 2 \\
\hline pentodon & $1700-1920$ & 41.2 & 14.4 & 20.5 & $20-22$ & $3-3.25$ & $3-3.4$ & 49 & 4 \\
\hline pesavis & $1080-1170$ & $?$ & $?$ & $5-8$ & 11 & 5 & $2.5 \mathrm{calc}$ & $29-31$ & 3 \\
\hline proximus & $1128-1400$ & $21-22$ & $10.6-12$ & minute & $25 \%$ calc & 3 & 2.8 calc & 24 & $1(?)$ \\
\hline pugettensis & $1310-2230$ & $26.3-40.5$ & $7-10$ & $5-9$ & $10-10.5$ & 5 & $5.5-6.5$ & $46-54$ & $4-5$ \\
\hline quadriseta & 1210 & 31.8 & 6.6 & $8-9$ & 11.5 & 5 & 6.3 & 40 & $6-7$ \\
\hline rotundus & 705 & 25 & 7 & $3-4$ & 9 & 5 & $>4$ & 30 & 4 \\
\hline saradi & 817 & 27 & 10.6 & $8-11$ & 11 & 4.5 & 3 & 30 & 14 \\
\hline separatus & 680 & 26.8 & 9.8 & 7 & 9 & $4.5-5$ & $3-3.2$ & 25 & 1 \\
\hline spinulosus & 877 & 35 & 8.6 & 4 & 5 & $?$ & 5 calc & $\begin{array}{l}20 \text { (arch), } 16 \\
\text { (chord) }\end{array}$ & 6 \\
\hline truncatus & 1600 & 43.5 & 11.1 & $\begin{array}{l}0.5 \\
\text { diam.c.s. }\end{array}$ & $33 \%$ & 2.5 & 3.46 & 1.3 a.d. & 4 \\
\hline ternus & $800-1120$ & $33.7-37$ & $10.6-12.3$ & $5-6.5$ & $8-9$ & 3.5 & $2.7-3$ & 36 & $3+$ \\
\hline vancouverensis & $1890-1960$ & $34-35$ & $12.1-16$ & $3-4$ & 10 & 5.5 & 5 & 30 & 5 \\
\hline vitraeus & 960 & 20 & 10.7 & $3.5-5$ & $27-33 \%$ & 3.5 & $3-3.5$ & $23-26$ & 5 \\
\hline
\end{tabular}

Paracyatholaimus diva sp. nov.

Figs 3-6

Type material:Holotype: male 1, two paratype males $2 \& 3$ and one paratype female mounted in glycerin on glass slides. Type specimens deposited in the DIVA nematode collection DZMB-Senckenberg, Südstrand 44, 26382 Wilhelmshaven, Germany.

Type locality: DIVA I, Meteor 48/1, Station 325/4, multicorer 8: South-east Atlantic Ocean, $19^{\circ} 58.3^{\prime} \mathrm{S}$ \& $002^{\circ} 59.8^{\prime} \mathrm{E}$, depth $5450 \mathrm{~m}$. 14 July 2000.

Etymology: the species name is derived from the acronym DIVA.

Morphometric data: Table 2. 
TABLE 2. Morphometry of Paracyatholaimus diva sp. nov.

\begin{tabular}{|c|c|c|c|c|}
\hline \multirow[t]{3}{*}{ Label } & \multicolumn{4}{|c|}{ Specimens \& labels } \\
\hline & 1 (holotype) & 2 (paratype) & 3 (paratype) & (paratype) \\
\hline & $\begin{array}{c}\text { Box B N 55(6) } \\
\text { DIVA I, M 48/1, } \\
\text { st. 325/4, MuC } 8\end{array}$ & $\begin{array}{c}\text { Box B N 55(7) } \\
\text { DIVA I, M 48/1, } \\
\text { st. 325/4, MuC } 8\end{array}$ & $\begin{array}{c}\text { Box B N 56(4) } \\
\text { DIVA I, M 48/1, } \\
\text { st. 325/4, MuC 8 }\end{array}$ & $\begin{array}{c}\text { Box B N 59(5) } \\
\text { DIVA I, M 48/1, } \\
\text { st. 325/4, MuC 8 }\end{array}$ \\
\hline $\mathbf{L}$ & 936 & 1120 & 1176 & 1147 \\
\hline $\mathbf{a}$ & 24.6 & 23.8 & 28 & 26.1 \\
\hline b & 6.65 & 7.00 & 7.35 & 6.23 \\
\hline c & 7.45 & 8.75 & 8.86 & 8.64 \\
\hline $\mathrm{V}(\%)$ & - & - & - & 46 \\
\hline diam.c.s. & 17 & $\sim 17$ & 19 & 18 \\
\hline diam.am. & 23.5 & $?$ & 22 & 30 \\
\hline diam.n.r. & 34 & 31 & 39 & 32 \\
\hline \multirow[t]{2}{*}{ diam.ca. } & 38 & 40 & 41 & 39 \\
\hline & 38 & 47 & 42 & 44 \\
\hline a.d. & 33 & 39 & 40 & 30 \\
\hline c.s.+o.l.s. & $3+3.5$ & $?$ & $3.5+4$ & $3.5+5$ \\
\hline c.s.+o.l.s. (\%) & $17.5+20.5$ & $?$ & $18.5+21$ & $19.5+27.5$ \\
\hline am.w. & 12.5 & $?$ & 14 & 8 \\
\hline am.w. (\%) & 53 & $?$ & 64 & 26.5 \\
\hline dis.am. & 11.5 & $?$ & 11 & 4 \\
\hline st.w. & 7 & $?$ & 8 & 8 \\
\hline st.l. & 16.5 & $?$ & 15 & 18 \\
\hline cheil.l. & 5 & $?$ & 3.5 & 3.5 \\
\hline dors.t.l. & 12 & $?$ & 11 & 12 \\
\hline spic.chord & 34 & 36 & 34 & - \\
\hline spic.arc & 45 & 51 & 46.5 & - \\
\hline gub.l. & 33 & 29 & 31 & - \\
\hline suppl.l. & 3 & $?$ & $?$ & - \\
\hline c' & 3.14 & 3.02 & 3.43 & 5.08 \\
\hline dist.tail part (\%) & 59 & 41 & 45 & 49.8 \\
\hline termin sp. & 7.5 & 8 & 7 & $?$ \\
\hline
\end{tabular}

Description. Body cylindrical. Cuticle transversally annulated and punctated. The dots (punctations) about the same size along the body and closely arranged in transversal rows. No clear lateral differentiation in size and position of the dots. The dots become a bit more distinct and convex to the amphid and to the anal region.

Anterior end truncate. Mouth opening surrounded by unclear conical lips with hardly visible inner labial sensilla. Outer labial and cephalic sensilla constitute a jointed circle of $6+4$ short setae. Four cephalic setae slightly smaller than six outer labial setae. Both outer labial and cephalic sensilla seem to be two-jointed, with the proximal joint thicker and at least twice as long as the distal joint. However, the jointed setae are often difficult to recognize in this species. The jointed nature of the outer labial setae is more evident in the female than in the males.

Amphidial fovea large, round or slightly transversally oval in outline, multispirally coiled with about six 
turns in the males and four turns in the female, situated at a distance from the apex. Amphidial fovea of the female notably smaller than that of the male. Cervical setae about four in number, situated laterally posterior to the amphid. There are very few small setae scarcely distributed along the body.

Cuticular pores indistinct in the pharyngeal region but become very obviously crater-shaped more posteriorly Cuticular pores arranged in two sublateral rows from the level of the cardia posteriad. There are 21 lateroventral pores and $\sim 37$ laterodorsal pores on the left body side of the holotype male.

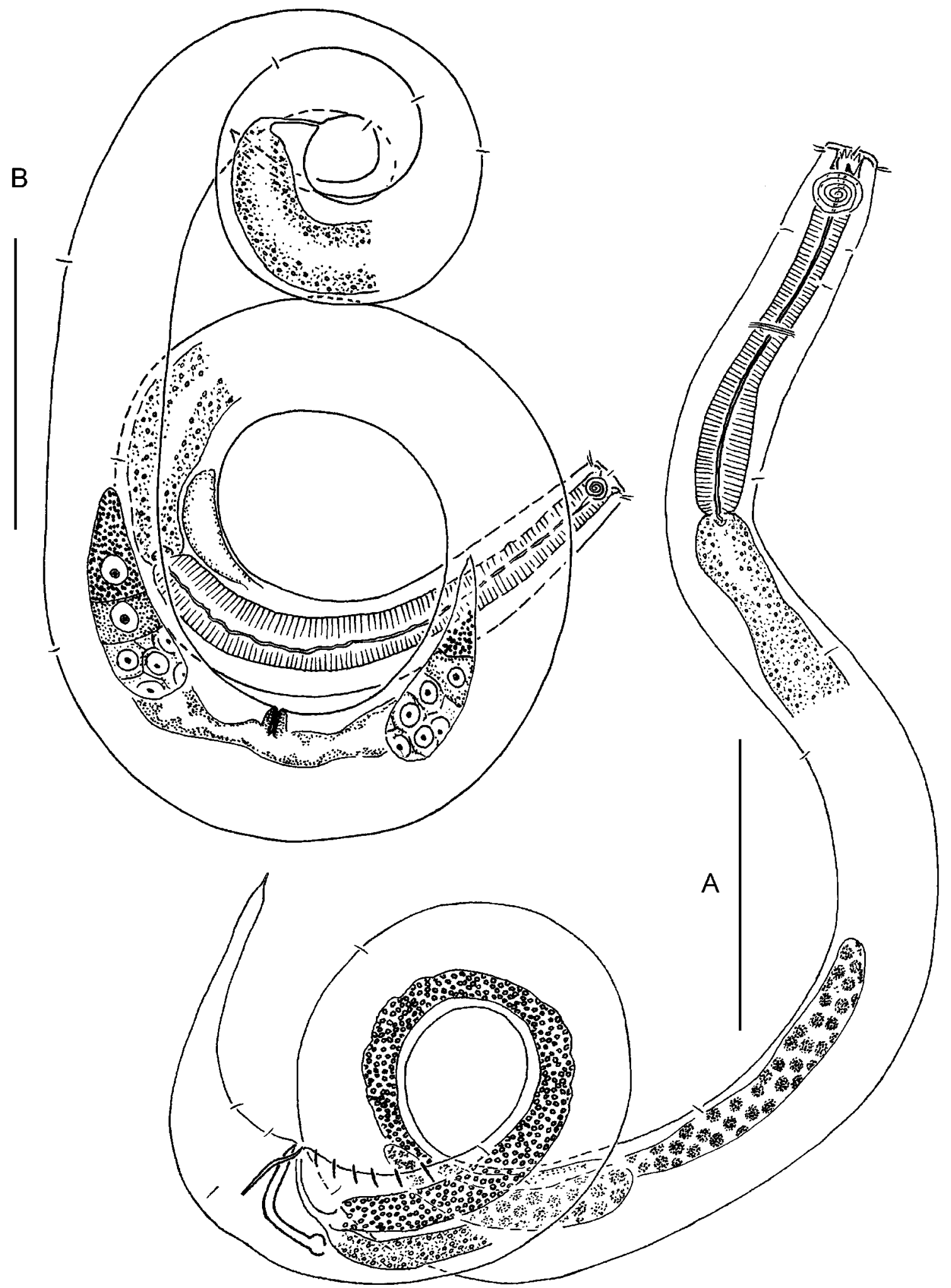

FIGURE 3. Paracyatholaimus diva sp. nov., entire. A: male N1 (holotype); B: female (paratype). Scale bars: $100 \mu \mathrm{m}$. 

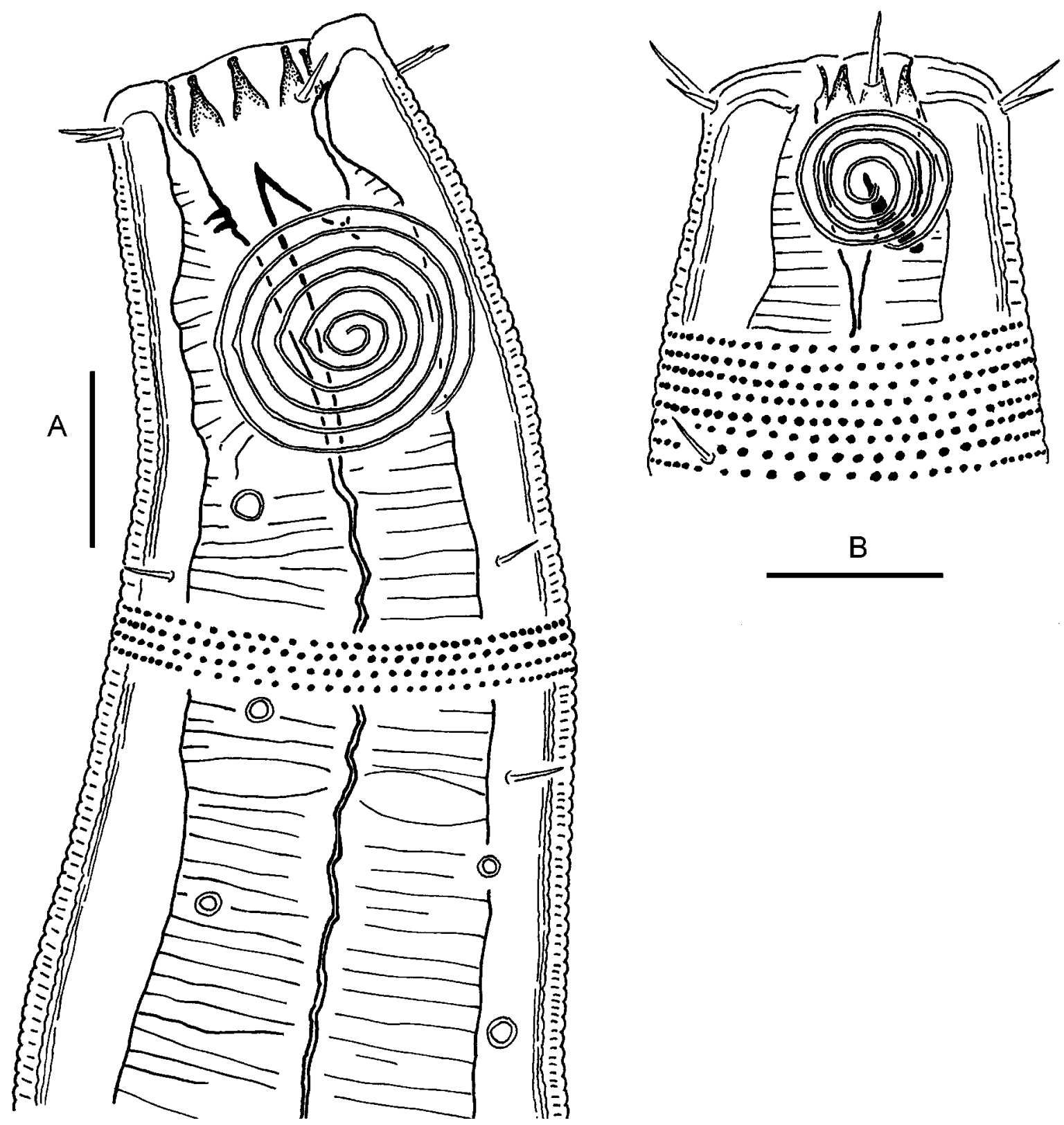

B

FIGURE 4. Paracyatholaimus diva sp. nov., anterior ends. A: male N1 (holotype); B: female (paratype). Scale bars: $10 \mu \mathrm{m}$.

Cheilostoma cup-shaped, its walls reinforced by triangular rugae apparently twelve in number. A big pointed sclerotized tooth on the dorsal side of the pharyngeal portion of the buccal cavity. There are no smaller opposite teeth, but obscure subventral cuticular hardenings in the buccal cavity.

Pharynx evenly muscular throughout its length, widening posteriorly but not forming a true bulb. Internal cuticular lining twisted and folded. Cardia poorly visible. Nerve ring hardly discernible in some specimens. Renette cell not found except an oval body just posterior to the cardia ventrally.

Didelphic, ovaries antidromously reflected; anterior ovary situated subventrally to the right of the intestine, posterior ovary subventrally to the left of the intestine. Diorchic; anterior testis outstretched, posterior smaller testis reflexed. Anterior testis situated to the right of the intestine, posterior testis to the left of the intestine. Spicules short, weak, sharply angularly bent, distally pointed, proximally with wide knobs. Gubernaculum paired, composed of two slightly sigmoid-curved platelets parallel to the distal portion of the spicules. Six supplementary organs arranged in a midventral preanal row. They look like thick conical setae one third protruded of cuticle and directed aslant anteriad. 

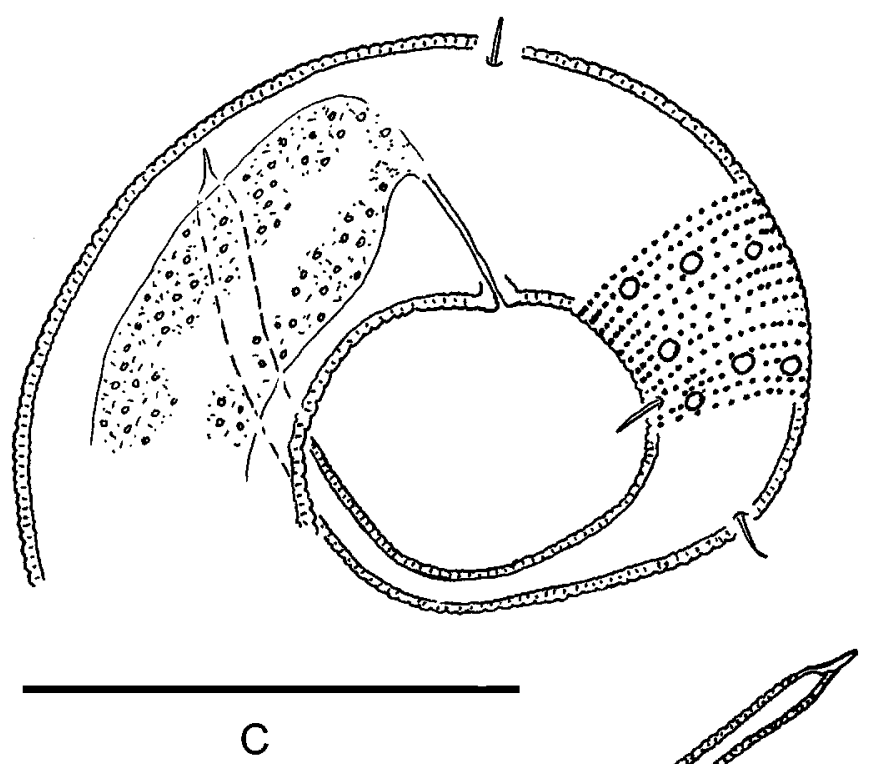

B

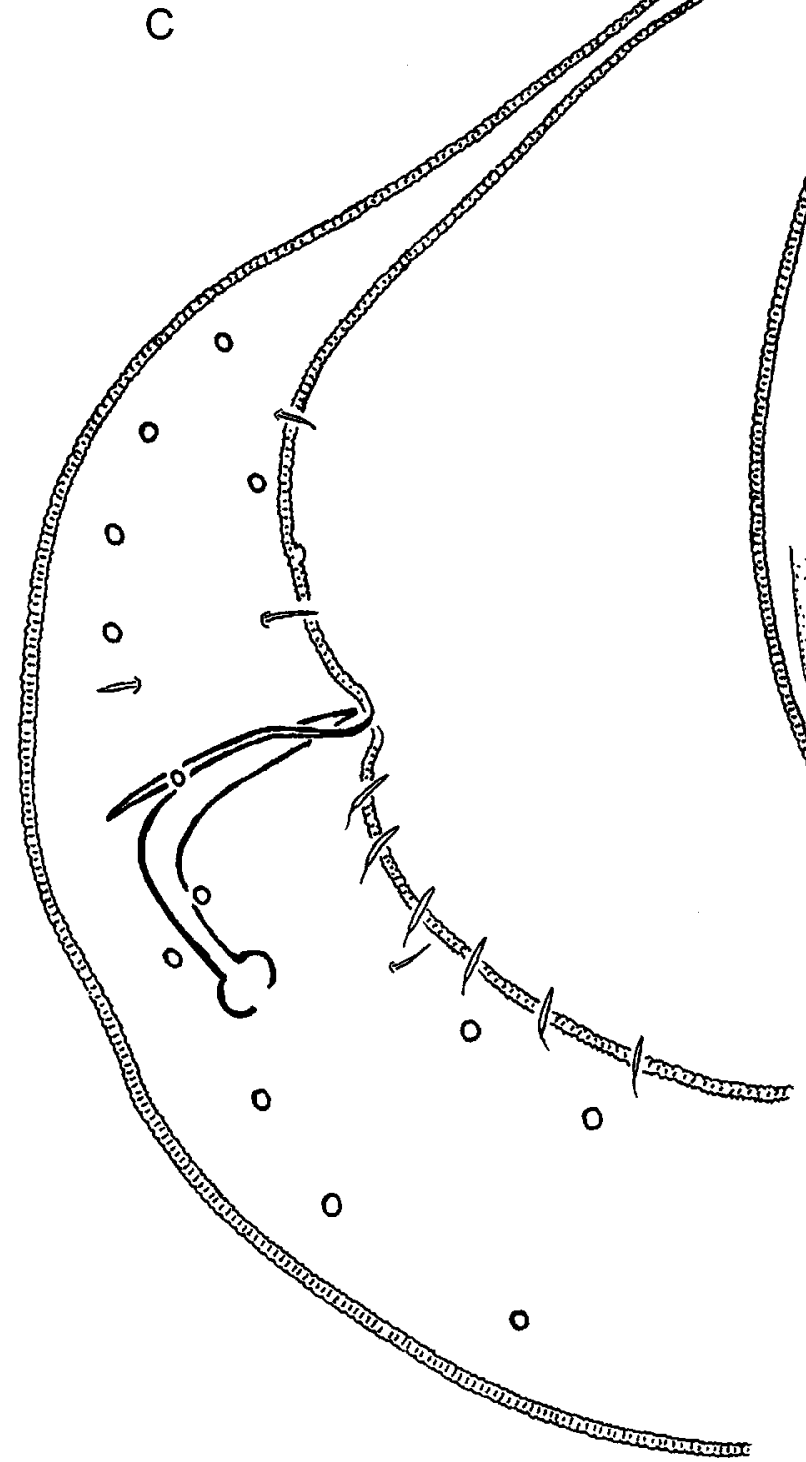

FIGURE 5. Paracyatholaimus diva sp. nov., details. A: male N1 (holotype), anterior body; B: male N1 (holotype), posterior end; C: female (paratype), posterior end. Scale bars: $50 \mu \mathrm{m}$. 


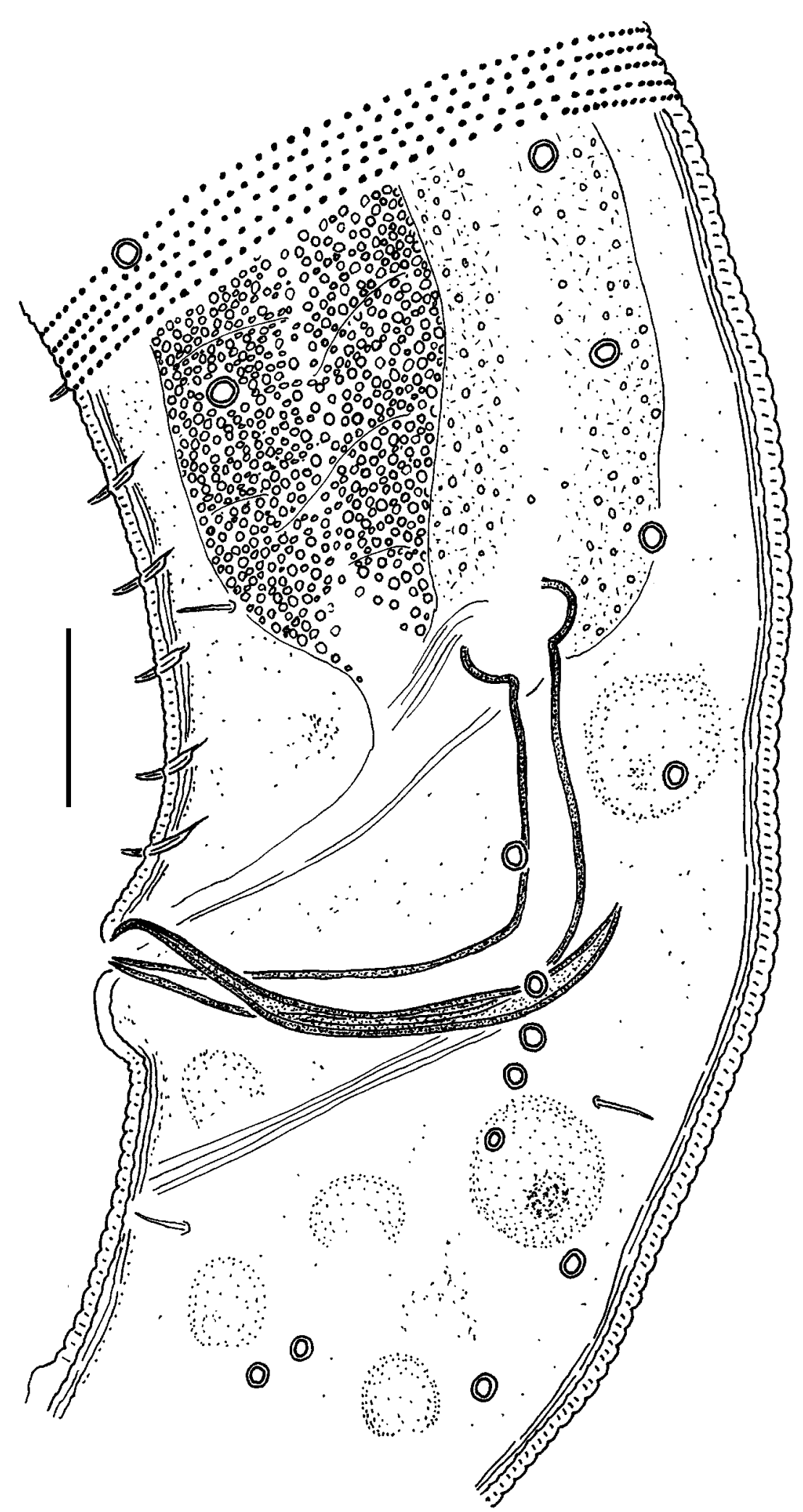

FIGURE 6. Paracyatholaimus diva sp. nov., cloacal region of the male N1 (holotype). Scale bar: $10 \mu \mathrm{m}$.

Tail of moderate length, consists of proximal conical and distal slender cylindrical portions, with delicate terminal spinnerete tube. There are a few short lateroventral setae on the tail.

Diagnosis: Paracyatholaimus. Body length 936-1176 $\mu \mathrm{m}$. No lateral differentiation in the cuticle. Outer labial and cephalic setae about 3.5-5 $\mu \mathrm{m}$. Amphidial fovea multispiral with six turns in males and four turns 
in females situated at the level of the dorsal tooth. Buccal cavity armoured with a prominent dorsal tooth and no subventral teeth. Tail consists of anterior conical and posterior slender cylindrical half portions. Diorchic, posterior testis reflexed. Spicules sharply bent, distally pointed, proximally knobbed. Gubernaculum distally narrowed and toothless. Six preanal midventral setose supplementary organs.

Differential diagnosis: The new species resembles Paracyatholaimus rotundus Gerlach, 1964 closer than other Paracyatholaimus species. P. rotundus is known from only one male specimen from the Red Sea. P. diva sp. nov. differs from $P$. rotundus by a slightly longer body (936-1176 $\mu \mathrm{m}$ versus $705 \mu \mathrm{m}$ ), tail shape (with clearly narrowed posterior half versus conical), six versus four supplementary organs of another shape.

$P$. diva sp. nov. shares large multispiral amphidial fovea with 5-6 turns with P. botosaneanui Andrássy, 1973, P. duplicatus Gerlach, 1964, P. paucipapillatus Gerlach, 1955, P. pugettensis Wieser \& Hopper, 1967, $P$. quadriseta (Wieser, 1954) and P. vancouverensis Sharma \& Vincx, 1982. P. diva sp. nov. differs from P. botosaneanui by slightly a thicker body (a 23.8-28 versus $31-33$ ), index c (7.45-8.86 versus $13.5-15)$, smaller cephalic setae (3-4 $\mu \mathrm{m}$ versus 10-12 $\mu \mathrm{m}$ ), longer spicules (34-36 $\mu \mathrm{m}$ versus $26-28 \mu \mathrm{m}$ ) and six versus four supplementary organs of another shape; from P. duplicatus by shorter body (936-1176 $\mu \mathrm{m}$ versus $1485 \mu \mathrm{m}$ ), smaller cephalic setae (3-4 $\mu \mathrm{m}$ versus $7-8 \mu \mathrm{m}$ ), relatively shorter nearly conical tail (c' 3.02-3.43 versus 5.56.5) and arrangement of supplementary organs (three distinct pairs in P. duplicatus); from P. paucipapillatus by shorter body (936-1176 $\mu \mathrm{m}$ versus $1445-1860 \mu \mathrm{m})$, index c (7.45-8.86 versus $13.9-14.1)$, much smaller cephalic setae (3-4 $\mu \mathrm{m}$ versus $8-15 \mu \mathrm{m}$ ) and six versus two supplementary organs; from P. pugettensis by shorter body (936-1176 $\mu \mathrm{m}$ versus 1310-2230 $\mu \mathrm{m}$ ), smaller cephalic setae (3-4 $\mu \mathrm{m}$ versus 5-9 $\mu \mathrm{m}$ ), relatively shorter tail (c'3.02-3.43 versus 5.5-6.5) and six versus four to five supplementary organs; from $P$. quadriseta by smaller cephalic setae (3-4 $\mu \mathrm{m}$ versus $8-9 \mu \mathrm{m}$ ) and relatively shorter tail (c'3.02-3.43 versus 6.3); from $P$. vancouverensis by shorter body (936-1176 $\mu \mathrm{m}$ versus $1890-1960 \mu \mathrm{m}$ ), relatively thicker body (a 23.8-28 versus 34-35), wider amphidial fovea (53-63\% versus $42 \%$ c.b.d.) and relatively shorter tail (c 7.458.86 versus $12.1-16$, c' $3.02-3.43$ versus 5$)$.

\section{Pomponema Cobb, 1917}

The genus was revised by Lorenzen (1972). An emended generic diagnosis of Pomponema is provided by Platt \& Warwick (1988). According to NeMys (Deprez et al. 2005), twenty-nine Pomponema species have been described up until recently.

\section{Pomponema proximamphidum sp. nov.}

Figs 7-9

Type material: Holotype male N1, two paratype males NN2 \& 3 mounted in glycerin on glass slides. Type specimens are deposited in the DIVA nematode collection.

Type locality: DIVA I, Meteor 48/1, Station 346/2, Multicorer 3: South-east Atlantic Ocean, $16^{\circ} 17.0^{\prime}$ S \& $005^{\circ} 27.0^{\prime}$ E, depth $5389 \mathrm{~m} .27$ July 2000.

Etymology: The species name reflects the position of amphids close to the labial position.

Morphometric data: Table 3.

Description. Body cylindrical, slender. Cuticle annulated and punctated with dots. Cuticle heterogeneous: thick, light-refracting, brownish in colour cuticle with sharp annules in the anterior body while thinner, lighter in colour cuticle with less sharply defined annules from about 0.4 pharynx length onwards. Anterior end characterized by large, distinct dots arranged in regular transversal rows becoming smaller towards the midpharynx and fusing thereafter into transversal lines. Lateral differentiations of the body cuticle begin just posterior 
to the amphidial fovea. Lateral differentiation expressed in a pattern of a sequence of paired big light-refractive dots sharply set off other lateromedian dots of the respective transversal row. The big dots in pairs joined by narrow dots. Space between big lateral dots about $7 \mu \mathrm{m}$ at the level of the nerve ring and $4 \mu \mathrm{m}$ on the midbody.

TABLE 3. Morphometry of Pomponema sp. nov.

\begin{tabular}{|c|c|c|c|}
\hline \multirow[t]{3}{*}{ Character } & \multicolumn{3}{|c|}{ Specimens \& labels } \\
\hline & 1 (holotype)* & 2 (paratype) & 3 (paratype) \\
\hline & $\begin{array}{c}\text { Box A N3(7) } \\
\text { DIVA I, M 48/1, } \\
\text { 346/2, MuC3 }\end{array}$ & $\begin{array}{c}\text { Box A N9(3) } \\
\text { DIVA I, M 48/1, } \\
\text { 346/2, MuC3 }\end{array}$ & $\begin{array}{c}\text { Box A N9(4) } \\
\text { DIVA I, M 48/1, } \\
\text { 346/2, MuC3 }\end{array}$ \\
\hline $\mathbf{L}$ & 911 & 1138 & 1203 \\
\hline $\mathbf{a}$ & 27.6 & 34 & $?$ \\
\hline b & 4.67 & 5.83 & 6.17 \\
\hline c & 4.00 & 6.03 & 5.87 \\
\hline diam.c.s. & 13 & 14 & 14 \\
\hline diam.am. & 19 & 19 & 20 \\
\hline diam.n.r. & 38 & 29 & 30 \\
\hline diam.ca. & 41 & 32 & 29 \\
\hline diam.midb. & 47 & 33.5 & $?$ \\
\hline a.d. & 27 & 24 & 24 \\
\hline o.l.s. & $2+5.5 * * *$ & $2+5$ & $2+5$ \\
\hline c.s. & 4.5 & 4 & 4 \\
\hline am.w. & 9 & 10.5 & 11.5 \\
\hline am.w. (\%) & 59 & 55 & 57.5 \\
\hline st.w. & 8 & 8 & 6 \\
\hline st.l. & 27 & 24 & 25 \\
\hline cheil.l. & 8 & 8 & 6 \\
\hline dors.t.l. & 17 & 19 & 18 \\
\hline dis.v.pore & 54 & 60 & 58 \\
\hline spic.chord & 33 & 33 & 35 \\
\hline spic.arc & 41 & 46 & 44.5 \\
\hline gub.l. & 21 & 19 & 17 \\
\hline suppl.n. & 14 & 13 & 13 \\
\hline suppl.l. & $7-6 * *$ & $8-7$ & $10-7$ \\
\hline c' & 8.12 & 7.45 & 7.89 \\
\hline dist.tail part (\%) & 62 & 52 & 52 \\
\hline termin sp. & $?$ & 3.5 & $3-4$ \\
\hline
\end{tabular}

*The specimen was slightly flattened while being measured.

**Anteriormost - posteriormost supplement

$* * *$ lateral + lateromedian sensilla

Inner labial sensilla indistinct. Outer labial and cephalic sensilla constitute together a common circle. Six outer labial setae differ notably to one another: lateral setae much shorter than lateromedian outer labial setae. Four cephalic setae a little shorter than the outer labial lateromedian setae. Cervical and somatic setae not 
found. There are few fuzzy cuticular pores in the pharyngeal region and no visible pores farther posteriad.

Amphidial fovea very large multispiral groove, ventrally coiled, with about five turns. It is half shifted to the apical surface of the head.
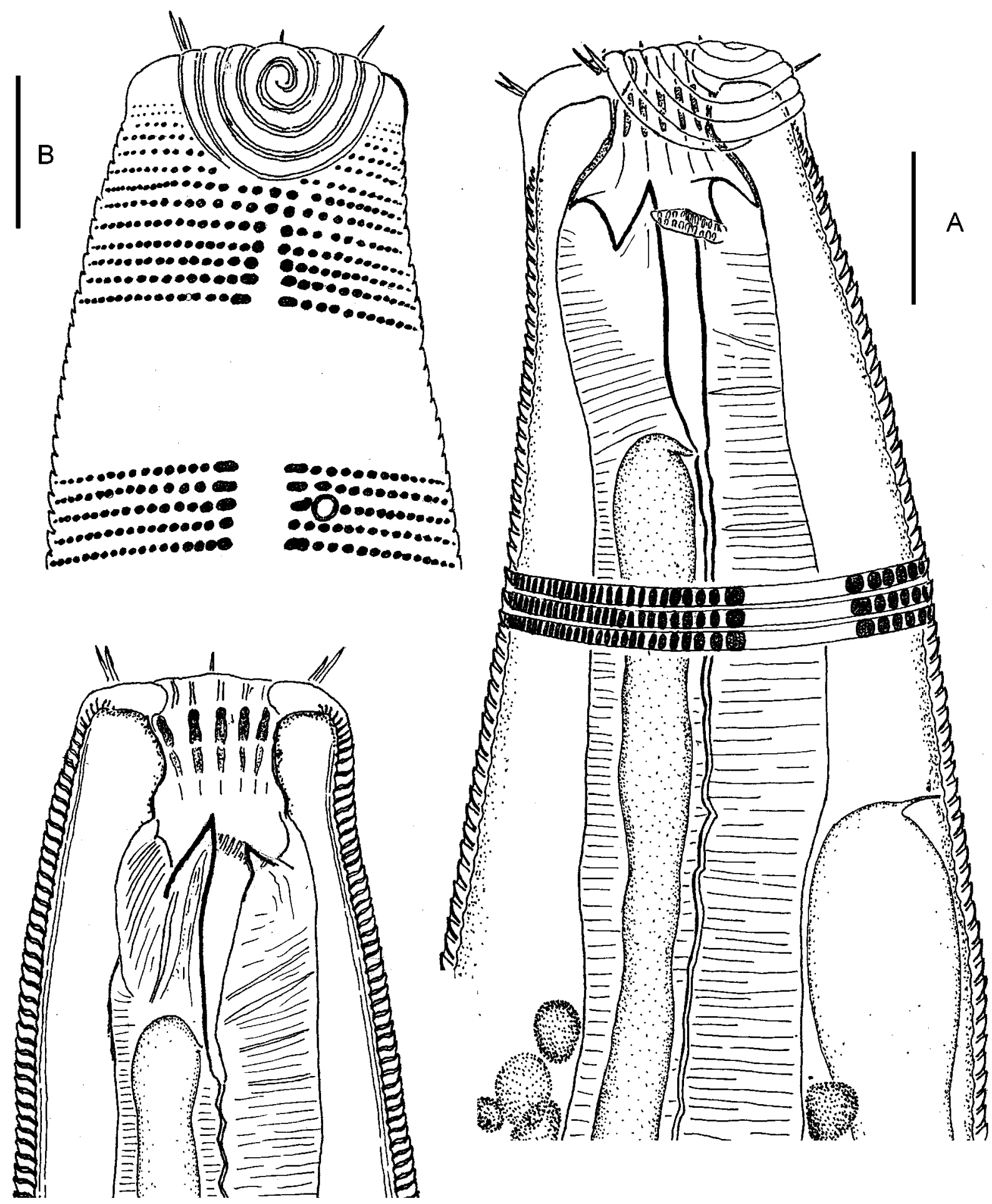

C

FIGURE 7. Pomponema proximamphidum sp. nov., anterior ends. A: male N1 (holotype), depicted right row of denticles; B: male N3 (paratype), surface view; C: male N3 (paratype), optical section, depicted left row of denticles. Scale bars: $10 \mu \mathrm{m}$. 

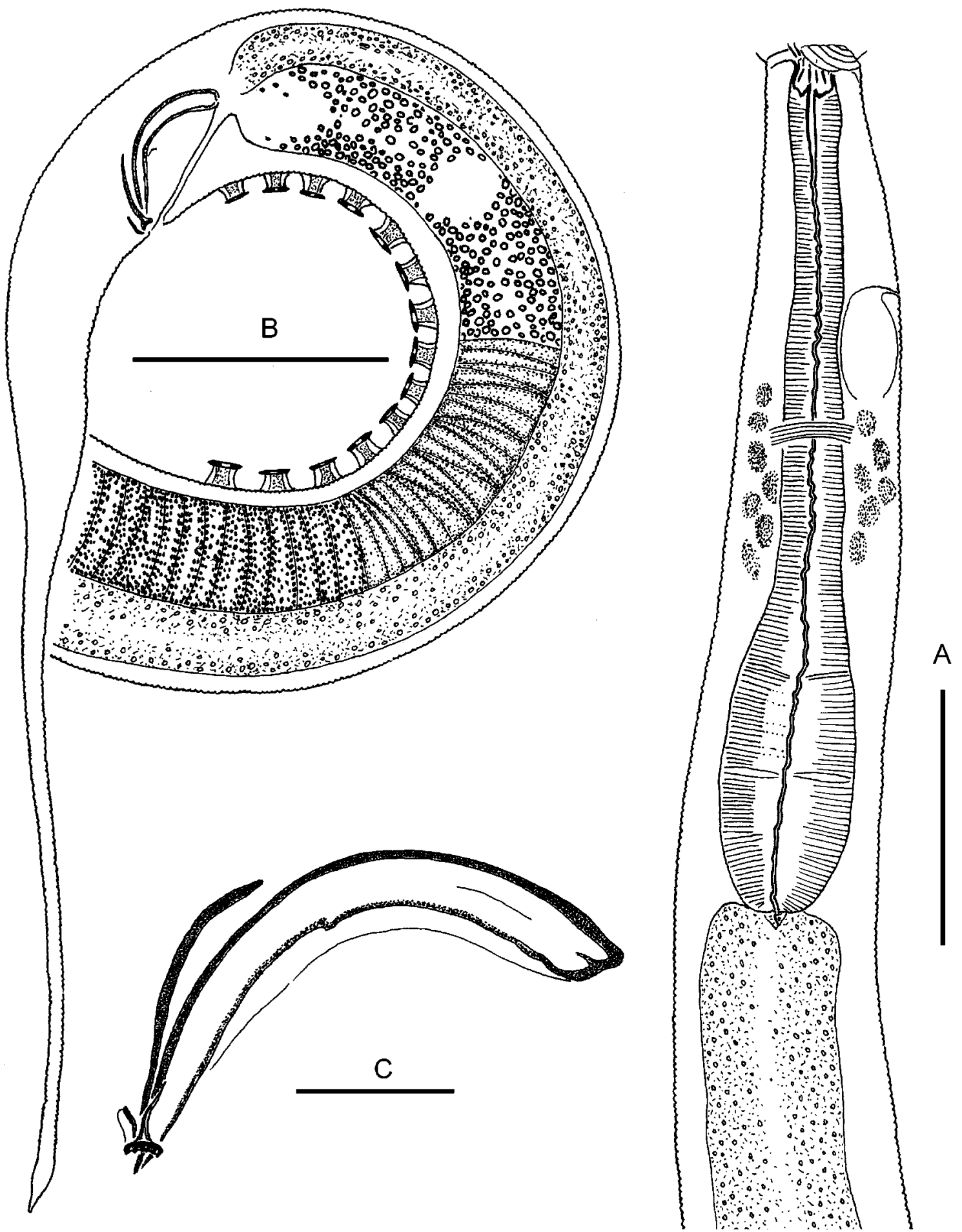

FIGURE 8. Pomponema proximamphidum sp. nov., details of the holotype male. A: anterior body; B: posterior end; C: copulatory apparatus. Scale bars: A, B $50 \mu \mathrm{m} ; \mathrm{C} 10 \mu \mathrm{m}$.

Buccal cavity differentiated into two compartments. Cheilostoma shaped as a truncate cone; its walls armoured with twelve stick-like ternary (three-storyed) rugae. Stegostoma provided with a big and acute dorsal tooth as well as two smaller subventral acute teeth. At the level of each side of the subventral teeth, a lateroventral row of six to eight tiny two-storyed dentlicles.

Pharynx evenly muscular throughout its length, slightly widening posteriorly but not forming a well defined bulb. Nerve ring well visible at the midpharynx. Terminal ampulla of the dorsal pharyngeal gland discernible at the base of the dorsal tooth. Cardia indistinct. There are rather large swallowed particles inside the 
intestine lumen.

Renette ampulla transparent and voluminous; ventral pore situated at a distance of about one third pharynx length from the anterior end.

Reproductive system diorchic. Both anterior outstretched and posterior reflected testes situated to the left of the intestine in all the specimens. Vas deferens consists of several parts (from anterior end caudad): medium granulated, finely granulated, homogeneous, and coarsely granulated.

Spicules short, arched, distally pointed and proximally widened. Gubernaculum as paired slightly curved plate distally adjoined to spicules. There is a small funnel-like structure with an indented sclerotized rim at each lateral side of the spicule distal tip.

Thirteen to fourteen midventral preanal supplementary organs. Each organ consists of a stout cylindrical body and a flat cover with a central opening. The supplementary organs may or may not be elevated above the body cuticle depending on the body curvature. There a small midventral sensilla just anterior to the cloacal opening.

Tail relatively long, consisting of proximal conical and slender cylindrical parts. A short terminal spinneret tube at the tail end. There are a few small setae laterally on the conical part.

Diagnosis. Male body length 911-1203 $\mu \mathrm{m}$. Cuticle heterogeneous: anteriormost cuticle thicker, brownish, with sharp annules in the anterior body while more posterior cuticle thinner, light, with less sharply defined annules. Lateral differentiation expressed in a pattern of a sequence of paired light-refractive dots sharply set off other much smaller lateromedian dots. Inner labial sensilla as conical papillae. Six outer labial sensilla differ notably to one another: labial sensilla as minute setae much shorter than lateromedian sensilla looking like true short setae. Four cephalic setae a little shorter than outer labial lateromedian setae. Amphidial fovea very large, multispiral, with about five turns; half shifted to the apical surface of the head. Stegostoma armoured by a big acute dorsal tooth, two smaller subventral acute teeth and two lateroventral rows of denticles at the level of the subventral teeth. Ventral pore situated at a distance of about one third pharynx length from the anterior end. Diorchic, posterior testis reflexed. Spicules short, arched, distally pointed and proximally widened. Gubernaculum as paired slightly curved plate with a small funnel-like structure with an indented sclerotized rim at each lateral side of the spicule distal tip. Thirteen to fourteen midventral preanal supplementary organs. Tail length $7.45-8.12$ anal diameters; its distal cylindrical part $52-62 \%$ of the entire tail.

Differential diagnosis: P. proximamphidum sp. nov. share the subapical position of the amphidial fovea and distinct lateral differentiation of the somatic cuticle with five other species: $P$. concinnum Wieser, 1954, $P$. corniculata Gourbault, 1980, P. mirabile Cobb, 1917, P. multipapillatum Filipjev, 1922 and P. stomachor Wieser, 1954.

P. proximamphidum sp. nov. differs from P. concinnum (Chile, $70-80 \mathrm{~m}$ ) with the index c' $(7.45-8.12$ versus 6), longer posterior cylindrical part of the tail (52-62\% versus $41 \%$ ), relative width of the amphidial fovea (55-59\% c.b.d. versus $40 \%$ c.b.d.), lesser number of supplementary organs (13-14 versus 20).

P. proximamphidum sp. nov. differs from $P$. corniculata, a geographically close species (Angola Basin, 2063-3615 m) with much longer tail (index c 4.00-6.03 versus $11.4-13.5$ and c' 7.45-8.12 versus $2.3-2.5$ ) with longer posterior cylindrical part of the tail (52-62\% versus $21 \%$ ), more anterior position of the ventral pore at about half the distance from the cephalic apex to the nerve ring versus just at the nerve ring (54-60 $\mu \mathrm{m}$ and $105 \mu \mathrm{m}$, respectively), bigger amphidial fovea (width 9-11.5 $\mu \mathrm{m}$ versus $7 \mu \mathrm{m}$ ), lesser number of supplementary organs (13-14 versus 20 ).

The original description of $P$. mirabile (no locality indicated by Cobb) misses some significant details and any indication on locality, hence the relation of the new species to $P$. mirabile remains unclear. However $P$. proximamphidum sp. nov. is distinctly separated from $P$. mirabile in the body length (911-1203 $\mu \mathrm{m}$ versus $>1800 \mu \mathrm{m}$ ), smooth versus jonted setae of the cephalic ring, smaller amphidial fovea (55-59\% c.b.d. versus $93 \%$ c.b.d.), lesser number of supplementary organs (13-14 versus 20$)$. 


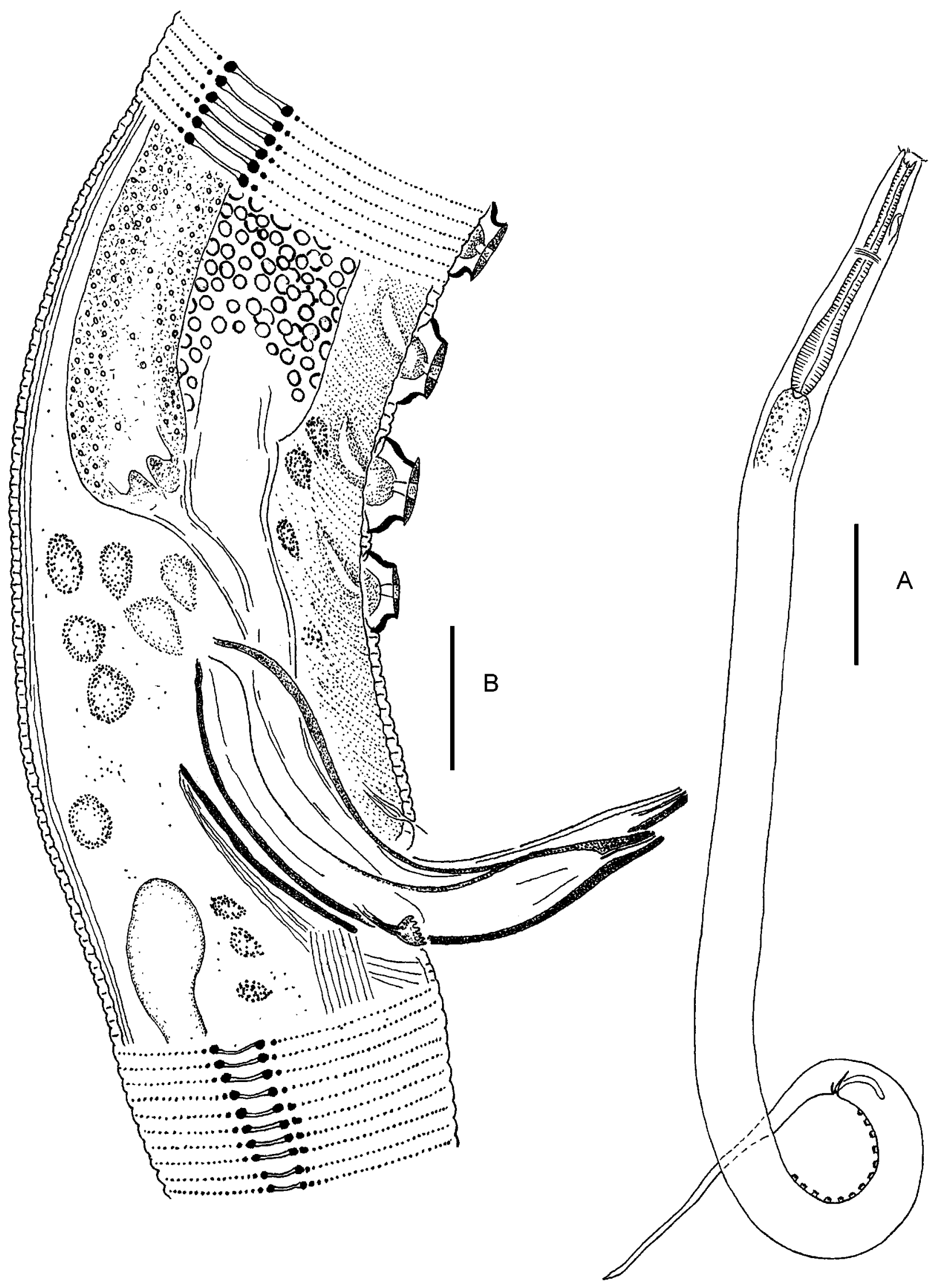

FIGURE 9. Pomponema proximamphidum sp. nov., details. A: male N1 (holotype), entire; B: male N3 (paratype), cloacal region. Scale bars: A $100 \mu \mathrm{m}$; B $10 \mu \mathrm{m}$. 
P. multipapillatum is known from two thorough descriptions of Filipjev (1922, Black Sea, sublittoral silt) and Lorenzen (1972, Helgoland in the North Sea, 30-34 m). P. proximamphidum sp. nov. differs from P. multipapillatum with much longer tail (index c 4.00-6.03 versus 7.3-10 and c' 7.45-8.12 versus 3.7-4.5) with longer posterior cylindrical part of the tail (52-62\% versus $28-44 \%$ ), position of the ventral pore (respectively 54-60 $\mu \mathrm{m}$ and $15-38 \mu \mathrm{m}$ from the cephalic apex to the ventral pore), shorter setae of the cephalic ring (2-4.5 $\mu \mathrm{m}$ versus 4-8 $\mu \mathrm{m}$ ), lesser number of supplementary organs (13-14 versus 15-19).

P. proximamphidum sp. nov. differs from $P$. stomachor (Chile, tidal exposed sand) by smaller body (911$1203 \mu \mathrm{m}$ versus 1950-2170 $\mu \mathrm{m}$ ), longer tail (index c 4-6.03 versus 7.1-8, c' 7.45-8.12 versus 7), much shorter setae of the cephalic crown (2-5.5 $\mu \mathrm{m}$ versus 3-18 $\mu \mathrm{m})$, smaller amphidial fovea (9-11.5 versus 20 $\mu \mathrm{m}$ ), shorter distance from the cephalic apex to the ventral excretory pore (width 54-60 $\mu \mathrm{m}$ versus 110-150 $\mu \mathrm{m}$ ), smaller spicules (33-44.5 $\mu \mathrm{m}$ versus $75 \mu \mathrm{m}$ ), lesser number of supplementary organs (13-14 versus 1519).

\section{Desmodoridae Filipjev, 1922 \\ Desmodora de Man, 1889}

Verschelde et al. (1998) proposed a taxonomic revision together with an emended generic diagnosis and a list of valid species of Desmodora. The list is supplemented in the NeMys database (Deprez et al. 2005).

\section{Desmodora striatocephala sp. nov.}

Figs 10-11

Type material: Holotype male. Type specimen deposited in the DIVA nematode collection.

Type locality: DIVA I, Meteor 48/1, Station 325/4, Multicorer 8: South-east Atlantic Ocean, 1958.3'S \& $002^{\circ} 59.8^{\prime} \mathrm{E}$, depth $5450 \mathrm{~m}$. 14 July 2000.

Etymology: The species name reflects fine cross striation of the head.

Description. Body cylindrical, of brownish-yellow colouration. Anterior end truncate. Somatic cuticle finely but distinctly annulated (just posterior to the cephalic capsule, nine annules for $10 \mu \mathrm{m}$ on convex body side and twelve annules on the opposite concave side; in the midbody, 17-20 annules for $10 \mu \mathrm{m}$ ), with no lateral differentiation.

Body length $1009 \mu \mathrm{m}$, a 34.8, b 7.6, c 7.4. Body diameter at the level of: cephalic setae $16 \mu \mathrm{m}$, amphidial fovea $21 \mu \mathrm{m}$, nerve ring $29 \mu \mathrm{m}$, cardia $29 \mu \mathrm{m}$, midbody $29 \mu \mathrm{m}$, cloaca $24 \mu \mathrm{m}$.

Labial region slightly drawn inward and therefore inner and outer labial sensilla not discernible. There are four short cephalic setae $3 \mu \mathrm{m}$ long at anterior cephalic capsule. Cephalic capsule $18 \mu \mathrm{m}$ long, shaped by thick cuticle with very fine traces of fused annules; the annules of the cephalic capsule by a factor of 1.5-2 wider and much less distinct than postcapsular annules.

Amphidial fovea very large and occupies nearly the whole lateral surface of the cephalic capsule. Amphidial fovea loop-shaped, slightly longitudinally oval and narrowed to its anterior end. Exit site of the amphidial nerve is thus unusually situated at the anterior end of the fovea where descending and ascending branches contact with one another. Amphidial fovea width $16 \mu \mathrm{m}$ or $76 \%$ c.b.d; distance from the cephalic apex to the amphidial fovea 3-4 $\mu \mathrm{m}$.

Somatic setae arranged in longitudinal rows distinct in the pharyngeal region and becoming irregular in the intestinal region.

Cheilostoma indistinctly discernible because of the dense pigmentation. The subsequent part of the buccal cavity narrow, equal to the cephalic capsule. Walls of the buccal cavity and small but distinct dorsal tooth very weakly sclerotized. 


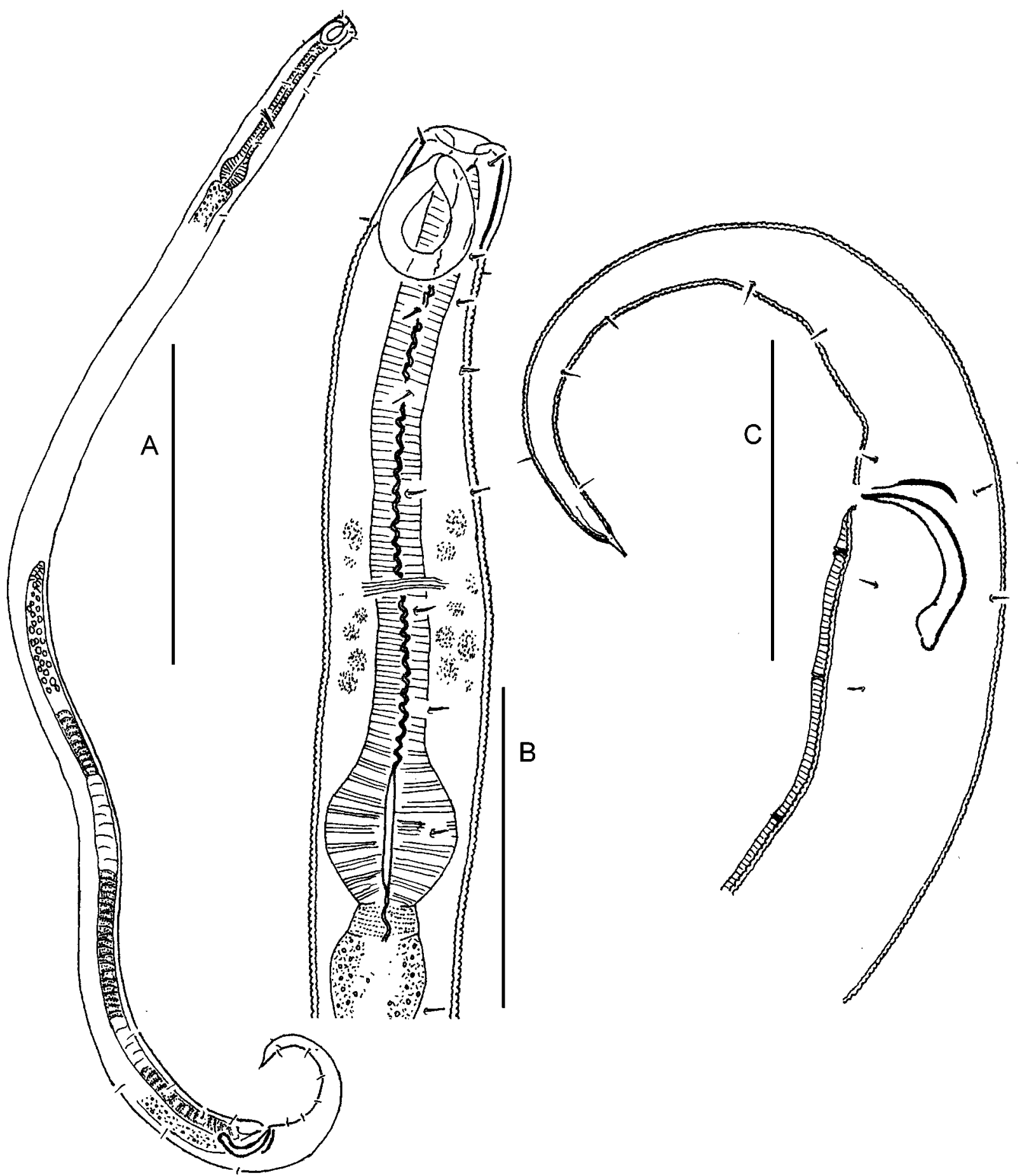

FIGURE 10. Desmodora striatocephala sp. nov., holotype male. A: total view; B: anterior body; C: posterior end. Scale bars: A 100 ìm; $\mathrm{B}, \mathrm{C} 50 \mu \mathrm{m}$.

Pharynx slender, evenly muscular, with sinuous cuticular lining of the internal lumen. Posteriorly, the pharynx widened into a clear roundish bulb. Pharynx width at the level of the nerve ring $13 \mu \mathrm{m}$; posterior bulb $24 \mu \mathrm{m}$ wide and $25 \mu \mathrm{m}$ long. Nerve ring hardly visible. No indication of a renette cell.

Cardia short, trapezium-shaped. Intestine with yellow-brownish inclusion droplets.

Testis singular, outstretched, situated ventrally to the intestine. Spermatozoa relatively large, of uncertain shape, with granular content. Vas deferens divided into alternate regions made up of cells with transparent and coarsely granulated content. 


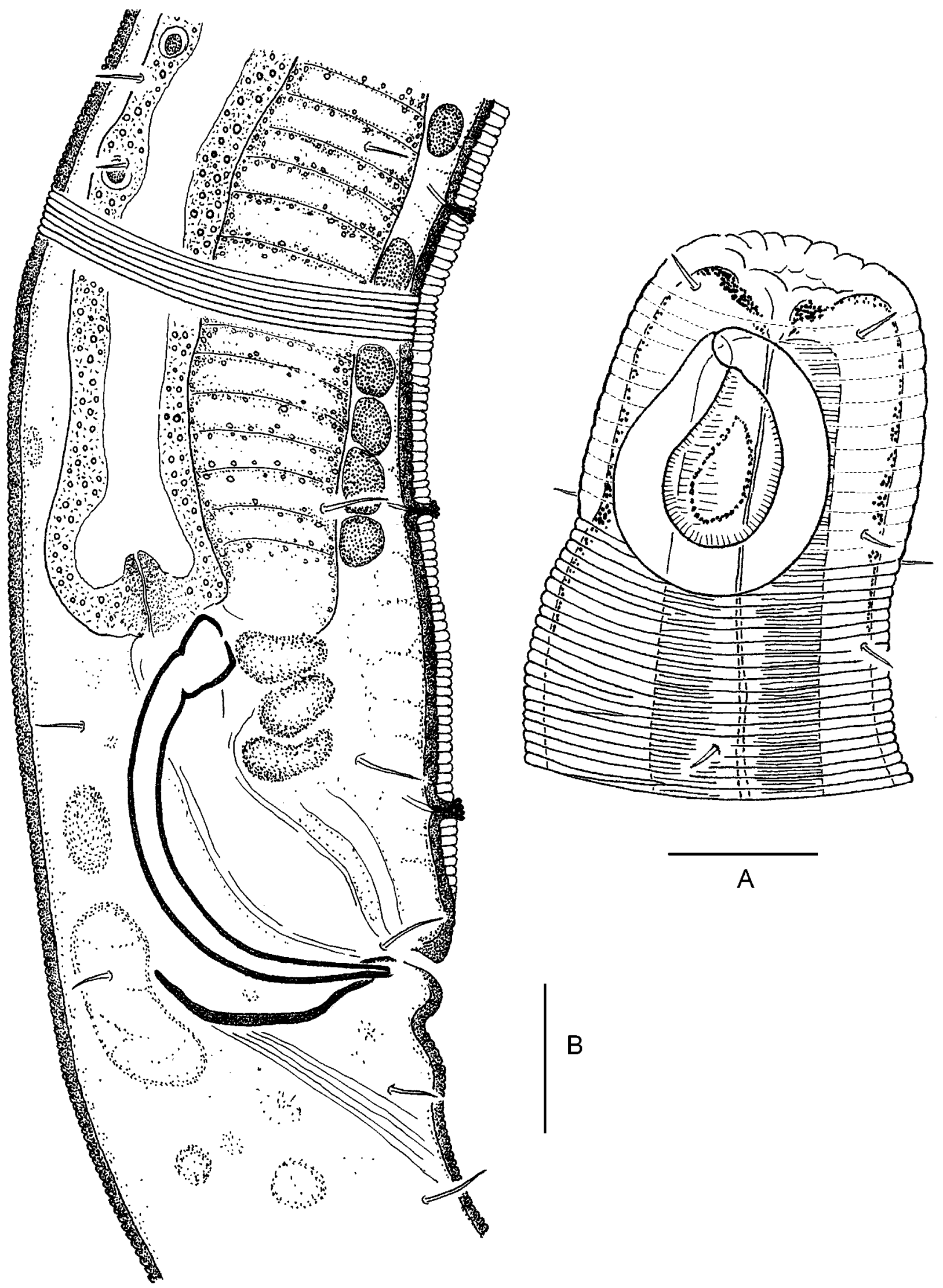

FIGURE 11. Desmodora striatocephala sp. nov., details of the holotype male. A: Anterior end; B: cloacal region. Scale bars: $10 \mu \mathrm{m}$. 
Spicules arched, distally pointed and proximally widened into shovel-like knobs, Gubernaculum paired, as two curved plates nearly parallel to the distal half of the spicules. Spicules length $29 \mu \mathrm{m}$ (chord) and $40 \mu \mathrm{m}$ (arch); gubernaculum plate $15 \mu \mathrm{m}$ long.

Precloacal ventral cuticle thickened and transparent. About five midventral supplementary organs inserted in the precloacal cuticle. Supplementary organ presents an intracuticular canal with a small papilla on the surface of the cuticle. The supplementary organs decrease in size from the cloaca anteriad.

Tail elongate conical, relatively slender, with terminal spinnerete tube. Tail length 5.32 anal diameters long. There a few pre- and postanal subventral setae on the posterior body; their length up to $4.5 \mu \mathrm{m}$, greater than those of the intestinal region.

Diagnosis. Body length $1009 \mu \mathrm{m}$, a 34.8, c 7.38. There are four short cephalic setae $3 \mu \mathrm{m}$ long at anterior cephalic capsule. Cephalic capsule $18 \mu \mathrm{m}$ long, shaped by thick cuticle with traces of fused annules; the annules of the cephalic capsule by a factor of 1.5-2 wider and much less distinct than postcapsular annules. Amphidial fovea very large and occupies nearly the whole lateral surface of the cephalic capsule. Amphidial fovea loop-shaped, slightly longitudinally oval and narrowed to its anterior end. Amphidial fovea width 16 $\mu \mathrm{m}$ or $76 \%$ c.b.d. Precloacal ventral cuticle thickened and transparent. About five midventral supplementary organs inserted in the precloacal cuticle. Supplementary organ present as an intracuticular canal with a small papilla on the surface of the cuticle. Tail elongate conical, relatively slender. Tail length 5.32 anal diameters long.

Differential diagnosis: Desmodora striatocephala sp. nov. is characterized by very fine but distinct cross striation of the cephalic capsule. Some related desmodorid genera such as Paradesmodora Stekhoven, 1950, Echinodesmodora Blome, 1982 and Stygodesmodora Blome, 1982 are also characterized by a cross-striated periamphidial cuticle hardly distinguishable from that of the neck region. However, the cephalic region of $D$. striatocephalata is clearly different in having a thickened cuticle with very fine transversal grooves thus forming a cephalic capsule set off the neck region with thinner cuticle and sharp grooves between annules.

Desmodora striatocephala sp. nov. is well characterized by a combination of very large amphidial fovea occupying nearly the entire lateral surface of the cephalic capsule and thickened midventral preanal cuticle with a few supplementary papillae inserted therein in males. The new species shares this set of features with D. cuddlesae Inglis, 1963 and to some lesser degree with D. inflexa Wieser, 1954. D. striatocephala sp. nov. differs from $D$. cuddlesae by the shorter body (1009 $\mu \mathrm{m}$ versus $1760-1980 \mu \mathrm{m})$, relatively longer tail (c 7.38 versus $13.5-14.1$, c' 5.32 versus $2.65-2.75)$, absolutely smaller but relatively bigger amphidial fovea (16 $\mu \mathrm{m}$ wide and $76 \%$ c.b.d. versus $26-37 \mu \mathrm{m}$ and $59 \%$ c.b.d.), about five versus twenty-nine preanal supplementary papillae in the ventral thickened transparent cuticle. D. striatocephala differs from D. inflexa with shorter body (1009 $\mu \mathrm{m}$ versus $2450 \mu \mathrm{m}$ ), relatively thicker body (a 34.8 versus 53.7), about five versus fourteen preanal supplementary papillae in the ventral thickened transparent cuticle and shorter tail (c 7.38 versus 25.8 , c' 5.32 versus 2.00 ). Other Desmodora species with ventrally thickened preanal cuticles are much more distinguished from $D$. striatocephala in other characters.

\section{Acknowledgements}

The author is greatly thankful to both anonymous reviewers for valuable remarks. This publication is a result of the DIVA-I expedition and the DFG project DIVANEMA (Sch-325/37-1). The visit of the author to DZMB-Senckenberg (German Centre for Marine Biodiversity Research), Wilhelmshaven, Germany in 2006 for initial sorting of the DIVA-I nematode collection was financially supported by the project of the Census of Diversity of Abyssal Marine Life (CeDAMar) and partly by Russian Fund of Basic Researches, grant 06-0448633. The author personally thanks Prof. Pedro Martínez Arbizu and Dr. Gunnar Gad for hospitality and many-sided help. 


\section{References}

Andrássy, I. (1973) Nematoden aus Strand- und Hohlenbiotopen von Kuba. Acta Zoologica Academiae Scientarum Hungaricae, 19, 233-270.

Bussau, C. (1990) Freilebende Nematoden aus Küstendünen und angrenzenden Biotopen der deutschen und dänischen Küsten. I. Gesamtüberblick und Chromadorida (Nematoda). Zoologischer Anzeiger (Jena), 225(3/4), 161-188.

Bütschli, O. (1874) Zur Kenntnis der freilebenden Nematoden, insbesondere der des Kieler Hafens. Abhandlungen der Senckenbergischen Naturforschen Gesellschaft, 9, 236-292.

Cobb, N. A. (1914) The North American free-living fresh-water nematodes. Transactions of the American Microscopical Society, 33, 69-119 (reprinted in Contributions to a Science of Nematology (Baltimore), 2, 35-99).

Coomans, A., Vincx, M. \& Decraemer, W. (1985) Nematodes from a freshwater pool on a coral island in the Solomon Islands. Hydrobiologia, 123, 265-281.

Deprez, T. and oth. (2005) NeMys. World Wide Web electronic publication. Available from: http://nemys.ugent.be (Version $8 / 2007)$.

Fonseca, G., Vanreusel A. \& Decraemer, W. (2006) Taxonomy and biogeography of Molgolaimus Ditlevsen, 1921 (Nematoda: Chromadoria) with reference to the origins of deep sea nematodes. Antarctic Science, 18(1), 23-50.

Gerlach, S.A. (1953a) Die Nematodenfauna der Uferzonen und des Küstengrundwassers am finnischen Meeresbusen. Acta Zoologica Fennica, 73, 1-32.

Gerlach, S.A. (1953b) Freilebende marine Nematoden aus dem Küstengrundwasser und aus dem Brackwasser der chilenischen Küste. Lunds Universitets Årsskrift. N. F. Avd. 2, 49(10), 1-37.

Gerlach, S.A. (1955) Zur Kenntnis der freilebenden marinen Nematoden von San Salvador. Zeitschrift für Wissenschaftliche Zoologie, 158, 249-303.

Gerlach, S.A. (1956) Diagnosen neuer Nematoden aus der Kieler Bucht. Kieler Meeresforschungen, 12, 85-109.

Gerlach, S.A. (1957) Marine Nematoden aus dem Mangrove-Gebiet von Cananéia (Brasilianische Meeres-Nematoden III). Akademie der Wissenschaften und Literatur, Mainz. Abhandlungen der Mathemathik-naturwissenschaftlichen Klasse, 5, 129-176.

Gerlach, S.A. (1964a) Freilebende Nematoden aus dem Roten Meer. Kieler Meeresforschungen, 20 (Sonderheft), 18 -34.

Gerlach, S.A. (1964b) Neue Cyatholaimidae (Nematoda Chromadorida) von den Malediven. Veröffentlichungen des Instituts für Meeresforschungen in Bremerhaven, 9, 70-78.

Gerlach, S.A. (1965) Freilebende Meeresnematoden aus der Gezeitenzone von Spitzbergen. Veröffentlichungen des Instituts für Meeresforschungen in Bremerhaven, 9, 109-172.

Gerlach, S.A. (1967) Freilebende Meeres-Nematoden von den Sarso-Inseln (Rotes Meer). Meteor-Forschungergebnisse (D), 2, 19-43.

Gerlach, S.A. \& Riemann, F. (1973) The Bremerhaven checklist of aquatic nematodes. A catalogue of Nematoda Adenophorea excluding the Dorylaimida. Part 1. Veröffentlichungen des Instituts für Meeresforschung in Bremerhaven, Supplement 4, Heft 1, 404 pp.

Hopper, B.E. (1972) Free-living marine nematodes from Biscayne Bay, Florida IV. Cyatholaimidae: On the occurence of Marylina n. gen. and Longicyatholaimus Micoletzky, 1924 in Biscayne Bay, with a description of L. longicaudatus (De Man, 1876) from the type locality. Zoologischer Anzeiger (Jena), 189, 64-88.

Jensen, P. (1985) The nematode fauna in the sulphide-rich brine seep and adjacent bottoms of the East Flower Garden, NW Gulf of Mexico. I. Chromadorida. Zoologica Scripta, 14(4), 247-263.

Kreis, H. (1963) Marine Nematoda. Zoology of Iceland, 2(14), 1-68.

Kröncke, I. \& Türkay, M. (2003) Structural and functional aspects of the benthic communities in the deep Angola Basin. Marine Ecology Progress Series, 260, 43-53.

Lorenzen, S. (1972) Die Nematodenfauna im Verklappungsgebiet für Industrieabwässer nordwestlich von Helgoland. III. Cyatholaimidae, mit einer Revision von Pomponema Cobb 1917. Veröffentlichungen des Instituts für Meeresforschungen in Bremerhaven, 13, 285-306.

de Man, J.G. (1880) Die einheimischen, frei in der reinen Erde und im süßen Wasser lebenden Nematoden monographisch bearbeitet. Vorläufiger Bericht und descriptiv-systematischer Theil. Tijdschrift der Nederlandsche dierkundige Vereeniging, 5, 1-104.

de Man, J.G. (1884) Die frei in der reinen Erde und im süßen Wasser lebenden Nematoden der niederländischen Fauna. Eine Systematisch-faunistische Monographie, Leiden 1884, 206 pp.

de Man, J.G. (1922) Vrijlevende Nematoden. In: H. C. Redeke (Ed.), Flora en Fauna der Zuiderzee, Te Helder (C. de Boer), pp. 214-261.

Meyl, A. H. (1954) Beiträge zur Kenntnis der Nematodenfauna vulkanisch erhitzter Biotope. III. Mitteilung. Nematoden aus der Mischungszone strandnaher, heisser Süßwasserquellen mit dem Meerwasser auf der Insel Ischia. Zeitschrift für Morphologie und Ökologie der Tiere, 42, 421-448.

Micoletzky, H. (1922) Die freilebenden Erdnematoden. Archiv für Naturgeschichte, 87A, 1-650.

Micoletzky, H. (1924) Letzter Bericht über freilebende Nematoden aus Suez. Sitzungsberichten der Akademie der Wis- 
senschaften in Wien, Mathematische-naturwissenschaft Klasse, Abteilung 1, 133, 137-179.

Platt, H.M. (1984) Pictorial taxonomic keys: their construction and use for the identification of freeliving marine nematodes. Cahiers de Biologie Marine, 25, 83-91.

Platt, H.M. \& Warwick, R.M. (1988) Free-living marine nematodes. Part II. British Chromadorids. Pictorial keys to world genera and notes for the identification of British species. Synopses of the British Fauna, 38. Publushed for the Linnean Society of London and the Estuarine and Brackish Water Sciences Association. By E.G. Brill IDr. W. Backhuys. Leiden, New York, København, Köln. 502 pp.

Riemann, F. (1966) Die interstitielle Fauna im Elbe-Ästuar. Verbreitung und Systematik // Archiv für Hydrobiologie, Supplement Band 31(1/2), 1-279.

Riemann, F. (1970) Freilebende Nematoden aus dem Grenzbereich Meer-Süß-Wasser in Kolumbien, Südamerika. Veröffentlichungen des Instituts für Meeresforschungen in Bremerhaven, 12, 365-412.

Rose, A., Seifried, S., Willen, E., George, K.H., Veit-Köhler, G., Bröhldick, K., Drewes, J., Moura, G., Martínez Arbizu, P. \& Schminke, H.K. (2005) A method for comparing within-core alpha diversity values from repeated multicorer sampling, shown for abyssal Harpacticoida (Crustacea: Copepoda) from the Angola Basin. Organisms, Diversity \& Evolution, 5, 3-17.

Sharma, J. \& Vincx, M. (1982) Cyatholaimidae (Nematoda) from the Canadian Pacific Coast. Canadian Journal of Zoology, 60, 271-280.

Verschelde, D., Gourbault, N. \& Vincx, M. (1998) Revision of Desmodora with descriptions of new desmodorids (Nematoda) from hydrothermal vents of the Pacific. Journal of the Marine Biological Association of the United Kingdom, $78,75-112$.

Wieser, W. (1954a) Free-living marine nematodes. II. Chromadoroidea. Lunds Universitets Årsskrift. N. F. Avd. 2, 50(16), 1-148.

Wieser, W. (1954b) Beiträge zur Kenntnis der Nematoden submariner Höhlen. Ergebnisse der österreichischen Tyrrhenia-Expedition 1952, Teil II. Österreichische zoologische Zeitschrift, 5, 172-230.

Wieser, W. (1959) Free-living nematodes and other small invertebrates of Puget Sound beaches. Seattle (University of Washington Press), 179 pp.

Wieser, W. \& Hopper, B. (1967) Marine nematodes of the east coast of North America. I. Florida. Bulletin of the Museum for Comparative Zoology 135(5), 239-344. 